\title{
The CUPID (Cultural and Psychosocial Influences on Disability) Study: Methods of Data Collection and Characteristics of Study Sample
}

\author{
David Coggon ${ }^{1 *}$, Georgia Ntani ${ }^{1}$, Keith T. Palmer ${ }^{1}$, Vanda E. Felli ${ }^{2}$, Raul Harari ${ }^{3}$, Lope H. Barrero ${ }^{4}$, \\ Sarah A. Felknor ${ }^{5,6}$, David Gimeno ${ }^{5}$, Anna Cattrell' ${ }^{7}$, Consol Serra ${ }^{8,9,10}$, Matteo Bonzini ${ }^{11}$, Eleni Solidaki ${ }^{12}$, \\ Eda Merisalu ${ }^{13}$, Rima R. Habib ${ }^{14}$, Farideh Sadeghian ${ }^{15}$, Masood Kadir ${ }^{16}$, Sudath S. P. Warnakulasuriya ${ }^{17}$, \\ Ko Matsudaira ${ }^{18}$, Busisiwe Nyantumbu ${ }^{19,20}$, Malcolm R Sim ${ }^{21}$, Helen Harcombe ${ }^{22}$, Ken Cox ${ }^{1}$, \\ Maria H. Marziale ${ }^{23}$, Leila M. Sarquis ${ }^{24}$, Florencia Harari ${ }^{3}$, Rocio Freire ${ }^{3}$, Natalia Harari ${ }^{3}$, \\ Magda V. Monroy ${ }^{4}$, Leonardo A. Quintana ${ }^{4}$, Marianela Rojas ${ }^{25}$, Eduardo J. Salazar Vega ${ }^{5}$, E. Clare Harris ${ }^{1}$, \\ Sergio Vargas-Prada ${ }^{8}$, J. Miguel Martinez ${ }^{8,9}$, George Delclos ${ }^{5,8,9}$, Fernando G. Benavides ${ }^{8,9}$, \\ Michele Carugno ${ }^{26}$, Marco M. Ferrario ${ }^{11}$, Angela C. Pesatori ${ }^{26,27}$, Leda Chatzi ${ }^{12}$, Panos Bitsios ${ }^{28}$, \\ Manolis Kogevinas ${ }^{29,30,31,32}$, Kristel Oha ${ }^{33}$, Tuuli Sirk ${ }^{34}$, Ali Sadeghian ${ }^{35}$, Roshini J. Peiris-John ${ }^{36,37}$, \\ Nalini Sathiakumar ${ }^{38}$, A. Rajitha Wickremasinghe ${ }^{39}$, Noriko Yoshimura ${ }^{40}$, Danuta Kielkowski ${ }^{19,20}$, \\ Helen L. Kelsall ${ }^{21}$, Victor C. W. Hoe ${ }^{21,41}$, Donna M. Urquhart ${ }^{21}$, Sarah Derett ${ }^{42}$, David McBride ${ }^{22}$, \\ Andrew Gray ${ }^{22}$
}

1 Medical Research Council Lifecourse Epidemiology Unit, University of Southampton, Southampton, UK, 2 School of Nursing, University of São Paulo, São Paulo, Brazil, 3 Corporación para el Desarrollo de la Producción y el Medio Ambiente Laboral - IFA (Institute for the Development of Production and the Work Environment), Quito, Ecuador, $\mathbf{4}$ School of Engineering, Pontificia Universidad Javeriana, Bogotá, Colombia, $\mathbf{5}$ Southwest Center for Occupational and Environmental Health, The University of Texas Health Science Center at Houston School of Public Health, Houston, Texas, United States of America, $\mathbf{6}$ Center for Disease Control and Prevention/National Institute for Occupational Safety and Health, Atlanta, Georgia, United States of America, 7 Medical Research Council Social, Genetic and Developmental Psychiatry Centre, Institute of Psychiatry, Kings College, London, UK, 8 Center for Research in Occupational Health (CiSAL), Pompeu Fabra University, Barcelona, Spain, 9 Carlos III Health Institute: Biomedical Research Networking Center of Epidemiology and Public Health, Granada, Spain, 10 Occupational Health Department, Parc de Salut MAR, Barcelona, Spain, 11 Epidemiology and Preventive Medicine Research Center, University of Insubria, Varese, Italy, 12 Department of Social Medicine, Medical School, University of Crete, Heraklion, Greece, 13 Department of Public health, University of Tartu, Tartu, Estonia, 14 Department of Environmental Health, Faculty of Health Sciences, American University of Beirut, Beirut, Lebanon, 15 Department of Occupational Health, Faculty of Health, Shahroud University of Medical Sciences, Shahroud, Iran, 16 Department of Community Health Sciences, Aga Khan University, Karachi, Pakistan, 17 Department of Medical Education and Health Sciences, Faculty of Medical Sciences, University of Sri Jayewardenepura, Gangodawila, Nugegoda, Sri Lanka, 18 Clinical Research Centre for Occupational Musculoskeletal Disorders, Kanto Rosai Hospital, Kawasaki, Japan, 19 National Institute for Occupational Health, National Health Laboratory Service, Johannesburg, South Africa, 20 Faculty of Health Sciences, University of Witwatersrand, Johannesburg, South Africa, 21 Department of Epidemiology and Preventive Medicine, School of Public Health and Preventive Medicine, Monash University, Melbourne, Victoria, Australia, 22 Department of Preventive and Social Medicine, University of Otago, Dunedin, New Zealand, 23 School of Nursing of Ribeirão Preto, University of São Paulo, São Paulo, Brazil, 24 Federal University of Paraná, Curitiba-PR, Brazil, 25 Institute for Studies on Toxic Substances (IRET), National University of Costa Rica, Heredia, Costa Rica, 26 Department of Occupational and Environmental Health, Università degli Studi di Milano, Milan, Italy, 27 Fondazione Ca' Granda Ospedale Maggiore Policlinico, Milan, Italy, $\mathbf{2 8}$ Department of Psychiatry, Medical School, University of Crete, Heraklion, Greece, 29 Centre for Research in Environmental Epidemiology (CREAL), Barcelona, Spain, 30 IMIM (Hospital del Mar Research Institute), Barcelona, Spain, 31 Consorcio de Investigación Biomédica de Epidemiología y Salud Pública (CIBERESP), Barcelona, Spain, 32 National School of Public Health, Athens, Greece, $\mathbf{3 3}$ North Estonia Medical Centre, Tallinn, Estonia, $\mathbf{3 4}$ Põlva Hospital, Põlva, Estonia, 35 Klinikum Leverkusen, Leverkusen, Germany, 36 Department of Physiology, Faculty of Medical Sciences, University of Sri Jayewardenepura, Gangodawila, Nugegoda, Sri Lanka, 37 Section of Epidemiology and Biostatistics, School of Population Health, Faculty of Medical and Health Sciences, University of Auckland, Auckland, New Zealand, 38 Department of Epidemiology, School of Public Health, University of Alabama at Birmingham, Birmingham, Alabama, United States of America, 39 Faculty of Medicine, University of Kalaniya, Kelaniya, Sri Lanka, $\mathbf{4 0}$ Department of Joint Disease Research, University of Tokyo, Tokyo, Japan, $\mathbf{4 1}$ Centre for Occupational and Environmental Health, Department of Social and Preventive Medicine, Faculty of Medicine, University of Malaya, Kuala Lumpur, Malaysia, 42 Injury Prevention Research Unit, Department of Preventive and Social Medicine, University of Otago, Dunedin, New Zealand 


\section{Abstract}

Background: The CUPID (Cultural and Psychosocial Influences on Disability) study was established to explore the hypothesis that common musculoskeletal disorders (MSDs) and associated disability are importantly influenced by culturally determined health beliefs and expectations. This paper describes the methods of data collection and various characteristics of the study sample.

Methods/Principal Findings: A standardised questionnaire covering musculoskeletal symptoms, disability and potential risk factors, was used to collect information from 47 samples of nurses, office workers, and other (mostly manual) workers in 18 countries from six continents. In addition, local investigators provided data on economic aspects of employment for each occupational group. Participation exceeded $80 \%$ in 33 of the 47 occupational groups, and after pre-specified exclusions, analysis was based on 12,426 subjects (92 to 1018 per occupational group). As expected, there was high usage of computer keyboards by office workers, while nurses had the highest prevalence of heavy manual lifting in all but one country. There was substantial heterogeneity between occupational groups in economic and psychosocial aspects of work; three- to fivefold variation in awareness of someone outside work with musculoskeletal pain; and more than ten-fold variation in the prevalence of adverse health beliefs about back and arm pain, and in awareness of terms such as "repetitive strain injury" (RSI).

Conclusions/Significance: The large differences in psychosocial risk factors (including knowledge and beliefs about MSDs) between occupational groups should allow the study hypothesis to be addressed effectively.

Citation: Coggon D, Ntani G, Palmer KT, Felli VE, Harari R, et al. (2012) The CUPID (Cultural and Psychosocial Influences on Disability) Study: Methods of Data Collection and Characteristics of Study Sample. PLoS ONE 7(7): e39820. doi:10.1371/journal.pone.0039820

Editor: Antony Bayer, Cardiff University, United Kingdom

Received April 10, 2012; Accepted May 28, 2012; Published July 6, 2012

Copyright: (c) 2012 Coggon et al. This is an open-access article distributed under the terms of the Creative Commons Attribution License, which permits unrestricted use, distribution, and reproduction in any medium, provided the original author and source are credited.

Funding: Funding for the central coordination of the CUPID study was provided by the UK Medical Research Council (www.mrc.ac.uk). In addition, support fo data collection in individual countries was obtained from the following sources: Brazil: Colt Foundation (www.coltfoundation.org.uk) (CF/03/05). Ecuador: Colt Foundation (www.coltfoundation.org.uk) (CF/03/05). Colombia: United States National Institutes of Health (NIH) (www.grants.nih.gov) Grant 5D43 TW00 0644-13, sub-award 0005919H; NIH Grant 5D43 TW00 0644-15, sub-award 0005919J; and Pontificia Universidad Javeriana (www.javeriana.edu.co). Costa Rica: Colt Foundation (www.coltfoundation.org.uk) (CF/03/05). Nicaragua: Colt Foundation (www.coltfoundation.org.uk) (CF/03/05). UK: Colt Foundation (www. coltfoundation.org.uk) (CF/03/05). Spain: Spanish Health Research Fund (www.imia.medinfo.org) (FIS 070422), and Epidemiology and Public Health CIBER Carlos III Institute of Health. Ministry of Science and Innovation. Italy: Department of Experimental Medicine, University of Insubria (www.unisubria.eu), Varese, Italy. Greece: Colt Foundation (www.coltfoundation.org.uk) (CF/03/05). Estonia: Colt Foundation (www.coltfoundation.org.uk) (CF/03/05). Lebanon: Colt Foundation (www.coltfoundation.org.uk) (CF/03/05). Iran: Deputy for Training and Research, Shahroud University of Medical Sciences (www.shmu.ac.ir). Pakistan: Colt Foundation (www.coltfoundation.org.uk) (CF/03/05). Sri Lanka: International Training and Research in Environmental and Occupational Health (ITREOH) Program of the University of Alabama at Birmingham (Grant number 5 D43 TWO5750 from the National Institutes of Health and the Fogarty International Center (NIH-FIC)) (www.fic.nih.gov/Programs/Pages/environmental-occupational-health.aspx). Japan: University of Tokyo (www.u-tokyo.ac.up/en/. South Africa: Colt Foundation (www.coltfoundation.org.uk) (CF/03/05). Australia: Monash University Strategic Grant Scheme and Monash University Near Miss Grant for NHMRC projects in 2008 (www.monash.edu.au). HLK and DMU were supported by Fellowships from NHMRC, and VCWH by the Ministry of Higher Education in Malaysia. New Zealand: Health Research Council of New Zealand (International Investment Opportunity Fund Grant) (www.hrc.govt.nz). The funders had no role in study design, data collection and analysis, decision to publish, or preparation of the manuscript.

Competing Interests: The authors have declared that no competing interests exist.

*E-mail: dnc@mrc.soton.ac.uk

\section{Introduction}

Musculoskeletal disorders of the back, neck and upper limb are a major cause of morbidity and disability with substantial economic impact, especially in western countries. In some cases symptoms arise from identifiable pathology in the spine or arm (e.g. a herniated inter-vertebral disc or peripheral nerve compression in the carpal tunnel). Most often, however, the underlying pathology is unclear, and the symptoms are classed as "nonspecific".

Epidemiological research has linked the occurrence of back, neck and upper limb disorders with various physical activities in the workplace [1-4], and also with psycho-social risk factors such as low mood and job dissatisfaction [5-8]. More recently, evidence has accumulated for a causal role also of "somatising tendency" (i.e. a general tendency to report and worry about common somatic symptoms) [6,9]. Together, however, these established risk factors do not adequately explain striking temporal changes that have been observed in disability attributed to common musculoskeletal complaints. For example, in Britain rates of incapacity for work because of back problems increased more than sevenfold between 1953 and 1992 at a time when the physical demands of work were generally reducing [10]; and in Australia there was a major epidemic of disability from arm pain during the early 1980s which was not paralleled in other countries where similar technologies and working methods were employed [11].

This gap in understanding has prompted the hypothesis that the development and persistence of non-specific musculoskeletal complaints and resultant disability are importantly influenced by culturally-determined health beliefs as well as by physical activities and mental health [12]. Several observations provide support for a role of health beliefs. For example, among 178 workers carrying out repetitive tasks on an assembly line in Mumbai, India, only one of whom had ever heard of "RSI" (repetitive strain injury), the 12 month prevalence of disabling arm pain $(5 \%)$ was less than one fifth of that found using the same questions among manual workers in the UK (including those who were of Indian subcontinental origin) [13]. In longitudinal studies of individuals with back and arm pain, negative beliefs about prognosis have proved predictive of their persistence $[7,14]$. And in Victoria, Australia, a 
Table 1. Specification and recruitment of study sample.

\begin{tabular}{|c|c|c|c|}
\hline $\begin{array}{l}\text { Country/Occupational } \\
\text { Group }\end{array}$ & Detailed description & Method of identification & $\begin{array}{l}\text { Method by which baseline } \\
\text { questionnaire completed }\end{array}$ \\
\hline \multicolumn{4}{|l|}{$\begin{array}{l}\text { SOUTH AND CENTRAL } \\
\text { AMERICA }\end{array}$} \\
\hline \multicolumn{4}{|l|}{ Brazil } \\
\hline Nurses & $\begin{array}{l}\text { Nurses, nursing technicians and auxiliaries at } \\
\text { the University Hospital in Sao Paolo }\end{array}$ & $\begin{array}{l}\text { Randomly sampled from a list } \\
\text { of eligible subjects provided by } \\
\text { managers }\end{array}$ & $\begin{array}{l}\text { Self-administered (in Brazilian } \\
\text { Portuguese) }\end{array}$ \\
\hline Office workers & $\begin{array}{l}\text { Computer users from an informatics centre } \\
\text { in Curitiba }\end{array}$ & $\begin{array}{l}\text { Randomly sampled from a list } \\
\text { of eligible subjects provided by } \\
\text { managers }\end{array}$ & $\begin{array}{l}\text { Self-administered (in Brazilian } \\
\text { Portuguese) }\end{array}$ \\
\hline Other workers & Sugar cane cutters at a mill in Ribeirao Preto & $\begin{array}{l}\text { Randomly sampled from a list } \\
\text { of eligible subjects provided by } \\
\text { managers }\end{array}$ & Interview (in Brazilian Portuguese) \\
\hline \multicolumn{4}{|l|}{ Ecuador } \\
\hline Nurses & Nursing staff at a Social Security hospital & $\begin{array}{l}\text { Quasi-random sampling from } \\
\text { employment records }\end{array}$ & Interview (in Spanish) \\
\hline Office workers & $\begin{array}{l}\text { Office workers regular using computers at the } \\
\text { Ministry of Public Health in Quito }\end{array}$ & $\begin{array}{l}\text { Quasi-random sampling from } \\
\text { employment records }\end{array}$ & Interview (in Spanish) \\
\hline Other workers & $\begin{array}{l}\text { Flower plantation workers in Tabacundo and } \\
\text { Cayambe, Pichincha }\end{array}$ & $\begin{array}{l}\text { Residents of specified blocks of } \\
\text { buildings surrounding the } \\
\text { flower plantations }\end{array}$ & Interview (in Spanish) \\
\hline \multicolumn{4}{|l|}{ Colombia } \\
\hline Office workers & $\begin{array}{l}\text { Office workers from the Javeriana University } \\
\text { in Bogota }\end{array}$ & $\begin{array}{l}\text { Quasi-random sampling from } \\
\text { employment records }\end{array}$ & $\begin{array}{l}\text { Self-administered by web } \\
\text { application (In Spanish) }\end{array}$ \\
\hline \multicolumn{4}{|l|}{ Costa Rica } \\
\hline Nurses & $\begin{array}{l}\text { Nurses, auxiliary nurses and nursing assistants } \\
\text { from two national hospitals in San Jose }\end{array}$ & $\begin{array}{l}\text { Randomly sampled from payroll } \\
\text { records }\end{array}$ & Interview (in Spanish) \\
\hline Office workers & $\begin{array}{l}\text { Office workers from the Central Offices of } \\
\text { the Costa Rican Social Security System }\end{array}$ & $\begin{array}{l}\text { Randomly sampled from payroll } \\
\text { records }\end{array}$ & Interview (in Spanish) \\
\hline Other workers & $\begin{array}{l}\text { Telephone call centre workers at the Duty Free } \\
\text { Zone in San Jose }\end{array}$ & $\begin{array}{l}\text { Randomly selected from payroll } \\
\text { records }\end{array}$ & Interview (in Spanish) \\
\hline \multicolumn{4}{|l|}{ Nicaragua } \\
\hline Nurses & $\begin{array}{l}\text { Nurses in internal medicine, surgery, orthopaedics, } \\
\text { gynaecology and paediatrics from two hospitals }\end{array}$ & $\begin{array}{l}\text { Randomly sampled from payroll } \\
\text { records }\end{array}$ & Self-administered (in Spanish) \\
\hline Office workers & $\begin{array}{l}\text { Secretaries and accountants with high computer } \\
\text { use at Ministry of Labor and Nicaraguan Institute } \\
\text { of Social Security }\end{array}$ & $\begin{array}{l}\text { Randomly sampled from payroll } \\
\text { records }\end{array}$ & Interview (in Spanish) \\
\hline Other workers & $\begin{array}{l}\text { Machine operators from two textile } \\
\text { manufacturing companies }\end{array}$ & $\begin{array}{l}\text { Sample identified from worker } \\
\text { members of the Maria Elena } \\
\text { Cuadra Movement }\end{array}$ & Interview (in Spanish) \\
\hline \multicolumn{4}{|l|}{ EUROPE } \\
\hline \multicolumn{4}{|l|}{ UK } \\
\hline Nurses & $\begin{array}{l}\text { Nurses from specified wards at Southampton } \\
\text { University Hospitals NHS Trust }\end{array}$ & From employment records & $\begin{array}{l}\text { Interview for random subsample; } \\
\text { remainder by self-administered } \\
\text { questionnaire }\end{array}$ \\
\hline Office workers & $\begin{array}{l}\text { Full-time clerical workers from three departments } \\
\text { at Houses of Parliament, London }\end{array}$ & From employment records & $\begin{array}{l}\text { Interview for random subsample; } \\
\text { remainder by self-administered } \\
\text { questionnaire }\end{array}$ \\
\hline Other workers & $\begin{array}{l}\text { Mail sorters from three Royal Mail centres in the } \\
\text { London area }\end{array}$ & From employment records & $\begin{array}{l}\text { Interview for random subsample; } \\
\text { remainder by self-administered } \\
\text { questionnaire }\end{array}$ \\
\hline \multicolumn{4}{|l|}{ Spain } \\
\hline Nurses & $\begin{array}{l}\text { All nurses and nursing assistants employed } \\
\text { for at least one year at } \\
\text { specified units of four hospitals in } \\
\text { Barcelona. }\end{array}$ & From employment records & Interview (in Spanish) \\
\hline Office workers & $\begin{array}{l}\text { All office workers from employed for at least one } \\
\text { year at specified units in four hospitals and one } \\
\text { University (UPF) in Barcelona. }\end{array}$ & From employment records & Interview (in Spanish) \\
\hline
\end{tabular}


Table 1. Cont.

\begin{tabular}{|c|c|c|c|}
\hline $\begin{array}{l}\text { Country/Occupational } \\
\text { Group }\end{array}$ & Detailed description & Method of identification & $\begin{array}{l}\text { Method by which baseline } \\
\text { questionnaire completed }\end{array}$ \\
\hline \multicolumn{4}{|l|}{ Italy } \\
\hline Nurses & $\begin{array}{l}\text { Nurses and nursing assistants at three } \\
\text { hospitals in Milan and Varese }\end{array}$ & From employment records & Self-administered (in Italian) \\
\hline Other workers & $\begin{array}{l}\text { Production workers at a factory making } \\
\text { pushchairs }\end{array}$ & From employment records & Self-administered (in Italian) \\
\hline \multicolumn{4}{|l|}{ Greece } \\
\hline Nurses & Nurses at Heraklion University Hospital & $\begin{array}{l}\text { Randomly sampled from } \\
\text { employment records }\end{array}$ & Interview (in Greek) \\
\hline Office workers & $\begin{array}{l}\text { Office workers at Heraklion University who were } \\
\text { registered as computer users }\end{array}$ & From employment records & Interview (in Greek) \\
\hline Other workers & $\begin{array}{l}\text { Postal clerks from the central post offices of } \\
\text { the four prefectures of Crete }\end{array}$ & From employment records & Interview (in Greek) \\
\hline \multicolumn{4}{|l|}{ Estonia } \\
\hline Nurses & $\begin{array}{l}\text { Nursing staff (nurses, technicians and auxiliaries) } \\
\text { at the University Hospital in Tartu and at } 31 \\
\text { institutions providing social care }\end{array}$ & $\begin{array}{l}\text { Randomly sampled from lists } \\
\text { provided by management }\end{array}$ & $\begin{array}{l}\text { Self-administered (in Estonian or } \\
\text { Russian) }\end{array}$ \\
\hline Office workers & $\begin{array}{l}\text { Secretaries and office workers in specified } \\
\text { departments at the University of Tartu }\end{array}$ & $\begin{array}{l}\text { Randomly sampled from lists } \\
\text { provided by management }\end{array}$ & $\begin{array}{l}\text { Self-administered (in Estonian or } \\
\text { Russian) }\end{array}$ \\
\hline \multicolumn{4}{|l|}{ ASIA } \\
\hline \multicolumn{4}{|l|}{ Lebanon } \\
\hline Nurses & Registered nurses at two hospitals & From employment records & Interview (in Lebanese Arabic) \\
\hline Office workers & Office workers at an academic institution & From employment records & Interview (in Lebanese Arabic) \\
\hline Other workers & Production workers at a food manufacturer & From employment records & Interview (in Lebanese Arabic) \\
\hline \multicolumn{4}{|l|}{ Iran } \\
\hline Nurses & Nurses at three university hospitals in Shahroud & $\begin{array}{l}\text { Through a nominated manager } \\
\text { at each organisation }\end{array}$ & Self-administered (in Farsi) \\
\hline Office workers & $\begin{array}{l}\text { Office workers at three university hospitals in } \\
\text { Shahroud and at four universities in Shahroud } \\
\text { (Shahroud University of Medical Sciences, } \\
\text { Shahroud University of Technology, Quran } \\
\text { Sciences University and Shahroud Azad University) }\end{array}$ & $\begin{array}{l}\text { Through a nominated manager } \\
\text { at each organisation }\end{array}$ & Self-administered (in Farsi) \\
\hline \multicolumn{4}{|l|}{ Pakistan } \\
\hline Nurses & $\begin{array}{l}\text { Nurses in in-patient services at Aga Khan } \\
\text { University Hospital, Karachi }\end{array}$ & From employment records & Interview (in Urdu) \\
\hline Office workers & $\begin{array}{l}\text { Full-time hospital receptionists at Aga Khan } \\
\text { University Hospital, Karachi }\end{array}$ & From employment records & Interview (in Urdu) \\
\hline Other workers & $\begin{array}{l}\text { Postal workers from Pakistan Post at two } \\
\text { sorting offices in Karachi }\end{array}$ & $\begin{array}{l}\text { Convenience sample of } \\
\text { workers from three shifts }\end{array}$ & Interview (in Urdu) \\
\hline \multicolumn{4}{|l|}{ Sri Lanka } \\
\hline Nurses & $\begin{array}{l}\text { Nursing officers at two tertiary care hospitals in } \\
\text { Colombo }\end{array}$ & $\begin{array}{l}\text { Randomly sampled from } \\
\text { employment records }\end{array}$ & Interview (in Sinhalese) \\
\hline Office workers & $\begin{array}{l}\text { Computer operators from six companies in } \\
\text { Colombo }\end{array}$ & $\begin{array}{l}\text { Randomly sampled from } \\
\text { employment records }\end{array}$ & Interview (in Sinhalese) \\
\hline Other workers (1) & $\begin{array}{l}\text { Postal workers at the Central Mail Exchange in } \\
\text { Colombo }\end{array}$ & $\begin{array}{l}\text { Randomly sampled from } \\
\text { employment records }\end{array}$ & Interview (in Sinhalese) \\
\hline Other workers (2) & $\begin{array}{l}\text { Sewing machinists at two garment factories in } \\
\text { Colombo District }\end{array}$ & $\begin{array}{l}\text { Randomly sampled from } \\
\text { employment records }\end{array}$ & Interview (in Sinhalese) \\
\hline \multicolumn{4}{|l|}{ Japan } \\
\hline Nurses & Nurses at Tokyo University Hospital & Through a nominated manager & Self-administered (in Japanese) \\
\hline Office workers & $\begin{array}{l}\text { Administrative and clerical workers at Tokyo } \\
\text { University Hospital and at four pharmaceutical } \\
\text { companies and a private trading company }\end{array}$ & $\begin{array}{l}\text { Through a nominated manager } \\
\text { at each organisation }\end{array}$ & Self-administered (in Japanese) \\
\hline Other workers (1) & $\begin{array}{l}\text { Transportation operatives (mainly lorry drivers } \\
\text { and loaders) at two companies transporting } \\
\text { baggage and mail }\end{array}$ & $\begin{array}{l}\text { Through a nominated manager } \\
\text { at each organisation }\end{array}$ & Self-administered (in Japanese) \\
\hline Other workers (2) & $\begin{array}{l}\text { Sales/marketing personnel at six pharmaceutical } \\
\text { companies }\end{array}$ & $\begin{array}{l}\text { Through a nominated manager } \\
\text { at each organisation }\end{array}$ & Self-administered (in Japanese) \\
\hline
\end{tabular}


Table 1. Cont.

\begin{tabular}{|c|c|c|c|}
\hline $\begin{array}{l}\text { Country/Occupational } \\
\text { Group }\end{array}$ & Detailed description & Method of identification & $\begin{array}{l}\text { Method by which baseline } \\
\text { questionnaire completed }\end{array}$ \\
\hline \multicolumn{4}{|l|}{ AFRICA } \\
\hline \multicolumn{4}{|l|}{ South Africa } \\
\hline Nurses & Nurses at two academic hospitals in Gauteng & $\begin{array}{l}\text { From nurses who were at work } \\
\text { when wards were visited }\end{array}$ & $\begin{array}{l}\text { Mostly interview with a few self- } \\
\text { administered (all in English) }\end{array}$ \\
\hline Office workers & Bank workers at a call centre & $\begin{array}{l}\text { From lists of workers provided by } \\
\text { the employer }\end{array}$ & Interview (in English) \\
\hline \multicolumn{4}{|l|}{ AUSTRALASIA } \\
\hline \multicolumn{4}{|l|}{ Australia } \\
\hline Nurses & $\begin{array}{l}\text { Nurses at AlfredHealth (The Alfred, Caulfield } \\
\text { Hospital and Sandringham Hospital), Melbourne }\end{array}$ & From employment records & Self-administered \\
\hline \multicolumn{4}{|l|}{ New Zealand } \\
\hline Nurses & $\begin{array}{l}\text { Nurses (Registered, Enrolled or nurse practitioners) } \\
\text { on the Nursing Council of New Zealand register }\end{array}$ & $\begin{array}{l}\text { Randomly selected from all nurses } \\
\text { holding a current practising certificate }\end{array}$ & Self-administered \\
\hline Office workers & $\begin{array}{l}\text { People on the } 2005 \mathrm{New} \text { Zealand electoral roll in } \\
\text { jobs likely to involve use of computers in offices }\end{array}$ & $\begin{array}{l}\text { Randomly selected from those on } \\
\text { electoral roll with relevant jobs }\end{array}$ & Self-administered \\
\hline Other workers & Mail sorters at New Zealand Post & $\begin{array}{l}\text { Randomly selected from an } \\
\text { employee database }\end{array}$ & Self-administered \\
\hline
\end{tabular}

doi:10.1371/journal.pone.0039820.t001

community-based intervention aimed at modifying people's beliefs and expectations about back pain was followed by a reduction in morbidity that was not paralleled in a control state [15].

This is not to say that common musculoskeletal symptoms never arise from traumatic injury to tissues. For the most part, however, such injuries would be expected to heal spontaneously over a period of days or weeks, as in other parts of the body. The influence of health beliefs, low mood and somatising tendency is likely to be more on the persistence of symptoms and levels of associated disability than on the occurrence of acute and transient symptoms.

If the hypothesised role of health beliefs were correct, it would have important practical implications. There might be scope for interventions aimed at modifying beliefs and expectations, along the lines of the successful campaign on back pain in Victoria, Australia [15]. More importantly, however, there would be a need for wider review of strategies aimed at preventing work-related musculoskeletal disorders. Currently, preventive efforts focus largely on reduction of physical stresses to the back and arm so as to minimise the risk of injury and maximise opportunities for continued employment in those who have developed symptoms. However, this approach may reinforce beliefs that even quite minor physical stresses (e.g. from use of a computer keyboard) can be seriously hazardous, and might thereby increase workers' vulnerability to long-term symptoms and disability.

The CUPID (Cultural and Psychosocial Influences on Disability) study was designed to explore further the impact of cultural and psychosocial influences on musculoskeletal symptoms and associated disability. It aims to compare the prevalence of symptoms and disability in workers who are carrying out jobs with similar physical demands, but in a range of cultural environments, and to explore risk factors for the incidence and persistence of symptoms and disability in these varying cultural environments. We here describe the methods by which participants have been recruited and data collected, summarise various characteristics of the study sample, and discuss strengths and limitations of the study method.

\section{Methods}

\section{Ethical Approval}

Ethical approval for the study was provided by the relevant research ethics committee or institutional review board in each participating country (Appendix S1). Written informed consent was obtained from all participants with the following exceptions. For self-administered questionnaires in the UK and Iran, information about the study was provided, and consent to the baseline survey was deemed to be implicit in the return of a completed questionnaire. In Lebanon, according to local practice, oral informed consent was obtained from all participants before interview, and this was recorded on a form signed and dated by the interviewer. In all cases, the method of obtaining consent was approved by the relevant research ethics committee.

\section{Overview}

The study focuses on 47 occupational groups from 18 countries (1-4 groups per country), from which information has been collected by means of an initial baseline questionnaire, followed by a further, shorter questionnaire after an interval of 12 months. Data collection in each country was led by a local investigator, who forwarded anonymised computerised data files to a team at the University of Southampton for collation and analysis (several earlier papers have described analyses based, all or in part, on components of the study in individual countries [16-22]). Local investigators also provided background information on the socioeconomic circumstances of their study cohorts - for example, on levels of unemployment in the local community and eligibility for sick pay and compensation for occupational injuries.

\section{Identification and Recruitment of Participants}

Local investigators were asked to recruit samples of nurses, office workers who regularly used a computer keyboard and/or mouse, and workers who carried out repetitive manual tasks with their arms or hands. Postal workers sorting mail were identified in advance as a group of manual workers who might be suitable for study, but other sources of manual workers were allowed at the 
Table 2. Response to baseline questionnaire.

\begin{tabular}{|c|c|c|c|c|}
\hline $\begin{array}{l}\text { Country/Occupational } \\
\text { Group }\end{array}$ & $\begin{array}{l}\text { Number of subjects } \\
\text { approached }\end{array}$ & $\begin{array}{l}\text { Number }(\%) \\
\text { participated }\end{array}$ & $\begin{array}{l}\text { Number of responders } \\
\text { excluded }\end{array}$ & $\begin{array}{l}\text { Number of } \\
\text { subjects analysed }\end{array}$ \\
\hline \multicolumn{5}{|l|}{ Brazil } \\
\hline Nurses & 200 & 192 (96\%) & 7 & 185 \\
\hline Office workers & 300 & 292 (97\%) & 11 & 281 \\
\hline Other workers & 300 & $182(61 \%)$ & 89 & 93 \\
\hline \multicolumn{5}{|l|}{ Ecuador } \\
\hline Nurses & 252 & 250 (99\%) & 31 & 219 \\
\hline Office workers & 250 & 250 (100\%) & 7 & 243 \\
\hline Other workers & 282 & 279 (99\%) & 52 & 227 \\
\hline \multicolumn{5}{|l|}{ Colombia } \\
\hline Office workers & 114 & 102 (89\%) & 10 & 92 \\
\hline \multicolumn{5}{|l|}{ Costa Rica } \\
\hline Nurses & 275 & 249 (91\%) & 29 & 220 \\
\hline Office workers & 275 & 249 (91\%) & 26 & 223 \\
\hline Other workers & 252 & 237 (94\%) & 32 & 205 \\
\hline \multicolumn{5}{|l|}{ Nicaragua } \\
\hline Nurses & 300 & 300 (100\%) & 18 & 282 \\
\hline Office workers & 300 & 300 (100\%) & 15 & 285 \\
\hline Other workers & 300 & 300 (100\%) & 103 & 197 \\
\hline \multicolumn{5}{|l|}{ UK } \\
\hline Nurses & 690 & $290(42 \%)$ & 33 & 257 \\
\hline Office workers & 1051 & 476 (45\%) & 96 & 380 \\
\hline Other workers & 1569 & 442 (28\%) & 56 & 386 \\
\hline \multicolumn{5}{|l|}{ Spain } \\
\hline Nurses & 716 & 687 (96\%) & 20 & 667 \\
\hline Office workers & 483 & $471(98 \%)$ & 33 & 438 \\
\hline \multicolumn{5}{|l|}{ Italy } \\
\hline Nurses & 766 & 585 (76\%) & 49 & 536 \\
\hline Other workers & 290 & 151 (52\%) & 12 & 139 \\
\hline \multicolumn{5}{|l|}{ Greece } \\
\hline Nurses & 240 & 224 (93\%) & 0 & 224 \\
\hline Office workers & 202 & 200 (99\%) & 1 & 199 \\
\hline Other workers & 154 & 140 (91\%) & 0 & 140 \\
\hline \multicolumn{5}{|l|}{ Estonia } \\
\hline Nurses & 876 & $423(48 \%)$ & 52 & 371 \\
\hline Office workers & 415 & $220(53 \%)$ & 18 & 202 \\
\hline \multicolumn{5}{|l|}{ Lebanon } \\
\hline Nurses & 193 & 186 (96\%) & 2 & 184 \\
\hline Office workers & 220 & 190 (86\%) & 18 & 172 \\
\hline Other workers & 172 & 168 (98\%) & 31 & 137 \\
\hline \multicolumn{5}{|l|}{ Iran } \\
\hline Nurses & 263 & 248 (94\%) & 2 & 246 \\
\hline Office workers & 213 & 187 (88\%) & 5 & 182 \\
\hline \multicolumn{5}{|l|}{ Pakistan } \\
\hline Nurses & 250 & 235 (94\%) & 48 & 187 \\
\hline Office workers & 216 & 216 (100\%) & 36 & 180 \\
\hline Other workers & 235 & $225(96 \%)$ & 3 & 222 \\
\hline \multicolumn{5}{|l|}{ Sri Lanka } \\
\hline Nurses & 250 & 237 (95\%) & 1 & 236 \\
\hline Office workers & 250 & 157 (63\%) & 5 & 152 \\
\hline
\end{tabular}


Table 2. Cont.

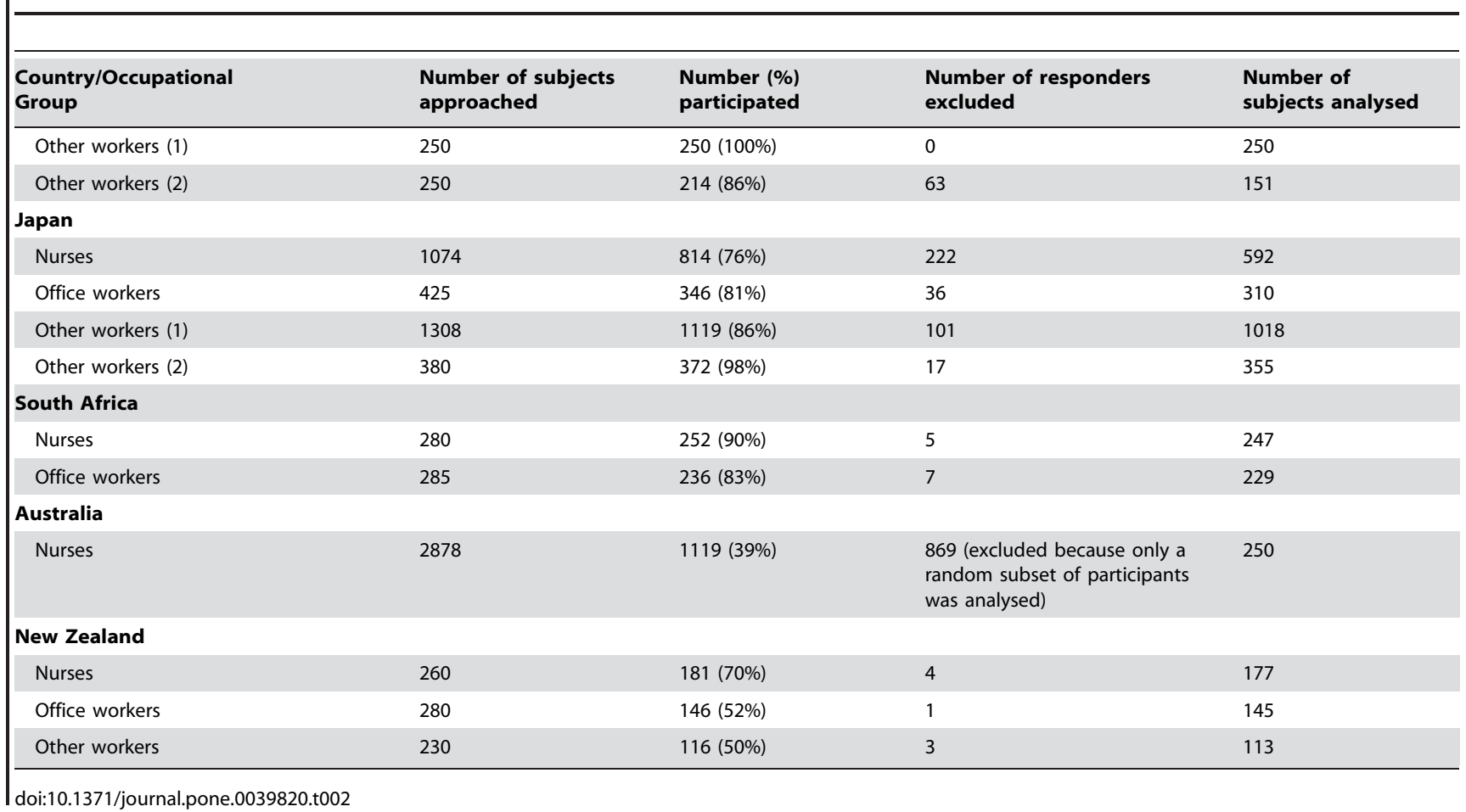

discretion of the local investigator. In one country (Japan), a group of sales and marketing workers was also recruited, and in the presentation and discussion of results, three main categories of occupation are distinguished - nurses, office workers, and "other workers", the last including the sales and marketing group as well as various manual occupations.

The aim was to restrict the international analysis to workers aged 20-59 years, who had been in their current job for at least 12 months. However, local investigators were free to recruit and carry out local analyses without these restrictions. Initial power calculations indicated that a sample size of 200 workers per occupational group would be more than adequate to detect differences between countries in the prevalence of symptoms and disability of the magnitude that was anticipated, and also for analysis of important risk factors for the incidence and persistence of pain at different anatomical sites in the longitudinal follow-up.

Table 1 describes the occupational groups that were selected for study, and the methods by which participants were identified and the baseline questionnaire administered. In most cases, potentially eligible subjects were identified from employers' records, sometimes with random sampling to achieve the desired sample size. Some occupational groups provided information at interview, and others by self-completion of questionnaires. In one country (UK), most questionnaires were self-completed, but random sub-samples of each occupational group were instead interviewed.

At the time of answering the baseline questionnaire, participants were asked whether they were willing to be re-contacted in the future, and those who agreed were asked (or will be asked) to complete a follow-up questionnaire after an interval of 12 months. In most cases, subjects have been followed up through their place of work, but where this was not possible (e.g. because they had left their original employer), they have been contacted at their home address. In each occupational group, follow-up questionnaires have been completed by the same method (interview or selfadministration) as the baseline questionnaire.

\section{Questionnaires}

The baseline questionnaire (Appendix S2) asked about demographic characteristics; education; height; smoking habits; current occupation; pain in different anatomical regions and associated disability for tasks of daily living; awareness of others with musculoskeletal pain; fear-avoidance beliefs concerning upper limb and low back pain; awareness of repetitive strain injury (RSI) or similar terms; distress from common somatic symptoms; mental health; and sickness absence in the past 12 months because of musculoskeletal problems and other types of illness.

The questions about current occupation covered working hours, whether the job involved each of a specified list of physical tasks, and psychosocial aspects of employment such as time pressures and targets, control over work organisation, support, satisfaction and job security. The questions about pain and disability focused on six anatomical regions (low back, neck, shoulder, elbow, wrist/ hand and knee) delineated in diagrams, and were similar in wording to questions that had been used successfully in earlier studies, both by self-administration $[9,23,24]$ and at interview [13]. The questions on fear-avoidance beliefs were adapted from the Fear Avoidance Beliefs Questionnaire [25]. Questions about distress from somatic symptoms were taken from the Brief Symptom Inventory (BSI) [26], and were chosen to provide a measure of the subject's tendency to somatise. Questions on mental health were taken from the Short Form-36 (SF-36) questionnaire [27].

The follow-up questionnaire (Appendix S3) asked about: any change of job since baseline and the reasons; recent pain in different anatomical regions and associated disability for tasks of daily living; distress from common somatic symptoms; mental health; and sickness absence in the past 12 months for musculoskeletal and other reasons. Where possible, the wording of questions was identical to that used in the baseline questionnaire. 
Table 3. Economic aspects of employment.

\begin{tabular}{|c|c|c|c|c|c|}
\hline $\begin{array}{l}\text { Country/ } \\
\text { Occupational } \\
\text { Group }\end{array}$ & $\begin{array}{l}\text { Local } \\
\text { unemployment } \\
\text { rate }(\%)\end{array}$ & $\begin{array}{l}\text { Social security } \\
\text { provision for } \\
\text { unemployed }\end{array}$ & $\begin{array}{l}\text { Sick pay in first } \\
\text { three months } \\
\text { absence }\end{array}$ & $\begin{array}{l}\text { Compensation for } \\
\text { work-related } \\
\text { musculoskeletal } \\
\text { disorders }\end{array}$ & $\begin{array}{l}\text { Special financial } \\
\text { support for ill- } \\
\text { health retirement }\end{array}$ \\
\hline \multicolumn{6}{|l|}{ Brazil } \\
\hline Nurses & $5-9$ & No & $\begin{array}{l}\text { Full for } 7 \text { days, but } \\
\text { not up to } 3 \text { months }\end{array}$ & Sometimes & No \\
\hline Office workers & $<5$ & No & Yes & Usually & Usually \\
\hline Other workers & $\geq 15$ & Yes & Partial from outset & Usually & No \\
\hline \multicolumn{6}{|l|}{ Ecuador } \\
\hline Nurses & $<5$ & No & $\begin{array}{l}\text { Full for } 7 \text { days, but } \\
\text { not up to } 3 \text { months }\end{array}$ & No & No \\
\hline Office workers & $5-9$ & No & $\begin{array}{l}\text { Full for } 7 \text { days, but } \\
\text { not up to } 3 \text { months }\end{array}$ & No & No \\
\hline Other workers & $<5$ & No & $\begin{array}{l}\text { Full for } 7 \text { days, but } \\
\text { not up to } 3 \text { months }\end{array}$ & No & No \\
\hline \multicolumn{6}{|l|}{ Colombia } \\
\hline Office workers & $5-9$ & No & Yes & Usually & Sometimes \\
\hline \multicolumn{6}{|l|}{ Costa Rica } \\
\hline Nurses & $<5$ & Up to 3 months & Yes & Usually & Usually \\
\hline Office workers & $<5$ & Up to 3 months & Yes & Usually & Usually \\
\hline Other workers & $<5$ & Up to 3 months & Yes & Usually & Usually \\
\hline \multicolumn{6}{|l|}{ Nicaragua } \\
\hline Nurses & $10-14$ & No & Yes & Usually & No \\
\hline Office workers & $10-14$ & No & Yes & Usually & No \\
\hline Other workers & $10-14$ & No & Yes & Usually & No \\
\hline \multicolumn{6}{|l|}{ UK } \\
\hline Nurses & $<5$ & Yes & Yes & Sometimes & Usually \\
\hline Office workers & $<5$ & Yes & Yes & Sometimes & Usually \\
\hline Other workers & $5-9$ & Yes & Yes & Sometimes & Usually \\
\hline \multicolumn{6}{|l|}{ Spain } \\
\hline Nurses & $5-9$ & Yes & Yes & Usually & Sometimes \\
\hline Office workers & $5-9$ & Yes & Yes & Usually & Sometimes \\
\hline \multicolumn{6}{|l|}{ Italy } \\
\hline Nurses & $5-9$ & Yes & Yes & Sometimes & No \\
\hline Other workers & $5-9$ & Yes & Yes & Sometimes & No \\
\hline \multicolumn{6}{|l|}{ Greece } \\
\hline Nurses & $5-9$ & Long-term only & Some workers & No & Sometimes \\
\hline Office workers & $5-9$ & Long-term only & Yes & No & Sometimes \\
\hline Other workers & $5-9$ & Long-term only & Yes & No & Sometimes \\
\hline \multicolumn{6}{|l|}{ Estonia } \\
\hline Nurses & $10-14$ & Yes & Full from 4 days & Usually & Sometimes \\
\hline Office workers & $10-14$ & Yes & Full from 4 days & Usually & Sometimes \\
\hline \multicolumn{6}{|l|}{ Lebanon } \\
\hline Nurses & $<5$ & No & $\begin{array}{l}\text { Full for } 7 \text { days, but } \\
\text { not up to } 3 \text { months }\end{array}$ & Sometimes & Usually \\
\hline Office workers & $5-9$ & No & $\begin{array}{l}\text { Full for } 7 \text { days, but } \\
\text { not up to } 3 \text { months }\end{array}$ & Usually & Sometimes \\
\hline Other workers & $5-9$ & No & $\begin{array}{l}\text { Full for } 7 \text { days for } \\
\text { some workers, but } \\
\text { not up to } 3 \text { months }\end{array}$ & Sometimes & Sometimes \\
\hline \multicolumn{6}{|l|}{ Iran } \\
\hline Nurses & $<5$ & Most workers & Yes & Sometimes & Sometimes \\
\hline Office workers & $5-9$ & Most workers & Yes & Sometimes & Sometimes \\
\hline
\end{tabular}


Table 3. Cont.

\begin{tabular}{|c|c|c|c|c|c|}
\hline $\begin{array}{l}\text { Country/ } \\
\text { Occupational } \\
\text { Group }\end{array}$ & $\begin{array}{l}\text { Local } \\
\text { unemployment } \\
\text { rate }(\%)\end{array}$ & $\begin{array}{l}\text { Social security } \\
\text { provision for } \\
\text { unemployed }\end{array}$ & $\begin{array}{l}\text { Sick pay in first } \\
\text { three months } \\
\text { absence }\end{array}$ & $\begin{array}{l}\text { Compensation for } \\
\text { work-related } \\
\text { musculoskeletal } \\
\text { disorders }\end{array}$ & $\begin{array}{l}\text { Special financial } \\
\text { support for ill- } \\
\text { health retirement }\end{array}$ \\
\hline \multicolumn{6}{|l|}{ Pakistan } \\
\hline Nurses & $<5$ & No & $\begin{array}{l}\text { Full for } 7 \text { days, but not } \\
\text { up to } 3 \text { months }\end{array}$ & No & No \\
\hline Office workers & $5-9$ & No & $\begin{array}{l}\text { Full for } 7 \text { days, but not } \\
\text { up to } 3 \text { months }\end{array}$ & No & No \\
\hline Other workers & $5-9$ & No & $\begin{array}{l}\text { Full for } 7 \text { days, but not } \\
\text { up to } 3 \text { months }\end{array}$ & No & No \\
\hline
\end{tabular}

doi:10.1371/journal.pone.0039820.t003

Both the baseline and follow-up questionnaires were compiled first in English. If necessary, they were then translated into local languages, and the accuracy of the translation was checked by independent back-translation to English. Where this revealed errors, appropriate corrections were made. In addition, in some countries, translated questionnaires were piloted in samples of workers who were not included in the main study, and where this revealed difficulties in understanding, further amendments were made.

Local investigators were at liberty to add to the "core" questions of the international study, and a few (e.g. in Italy, Greece, Iran, Japan, South Africa, Australia and New Zealand) took up this option. However, in doing so, they were asked where possible to place the supplementary questions after the core questions, so as to minimise the chance that they would alter the ways in which participants answered the core questions.

\section{Group-level Socio-economic Information}

As well as individual data on study participants, local investigators also provided standardised information about the socio-economic circumstances of the occupational groups which they had recruited. This included the local unemployment rate at the time of the survey, availability of social security support for the unemployed, entitlement to sick pay in the first three months of absence, entitlement to compensation for work-related musculoskeletal disorders, special financial support for ill-health retirement, fees paid for healthcare, and access to an occupational health service.

\section{Results}

\section{Response to Baseline Questionnaire}

The response to the baseline questionnaire is summarised in Table 2. Participation rates among those invited to take part in the study were greater than $80 \%$ in 33 of the 47 occupational groups, ranging from $28 \%$ in UK other workers and 39\% in Australian nurses to $100 \%$ in six occupational groups from Ecuador, Nicaragua, Pakistan and Sri Lanka. However, 2,279 participants were excluded from the international analysis because they fell outside the specified age range (310), had missing data (317), had not worked in their current job for as long as 12 months (783), or (in the case of Australian nurses) were excluded by random sampling (869). After these exclusions, a total of 12,426 workers were available for analysis, with between 92 and 1018 in each occupational group.

\section{Circumstances of Occupational Groups}

Table 3 summarises various economic aspects of employment for the occupational groups studied. The local rate of unemployment ranged from $<5 \%$ in 16 occupational groups to $\geq 15 \%$ in seven. Members of 28 groups would be eligible for social security provision if they became unemployed, although in the three groups from Costa Rica this would be limited to the first three months without a job. Almost all participants could receive some form of sick pay during the first three months of absence from work, but in 22 groups this would not compensate fully for all loss of earnings over that period. Some form of financial compensation for work-related musculoskeletal disorders was available to 40 occupational groups, but 19 groups were ineligible for any special financial support in the event of ill-health retirement.

Table 4 describes the access of participants to different sources of healthcare. Most participants had free access to doctors in primary care and hospitals, but fees were more often required for consultation of other health practitioners. All but nine occupational groups were covered by an occupational health service.

\section{Characteristics of Participants}

Table 5 gives information about the demographic characteristics of participants and their hours of work. In all countries, nurses were predominantly female, and in 18 occupational groups more than $90 \%$ of subjects were from one sex. Most groups had a broad distribution of ages, but in a few groups, younger $(<30$ years) or older ( $\geq 50$ years) workers were less well represented. Levels of education were generally high in nurses and office workers, but lower in many groups of "other workers". Most subjects had been in their current job for longer than five years, and most worked between 30 and 49 hours per week. However, in Pakistan, Sri Lanka and Japan, the prevalence of longer working hours $(>50$ hours per week) was high relative to other countries.

Table 6 shows the prevalence of different physical tasks by occupational group. As would be expected, a high proportion of office workers $(>80 \%$ in all but one group) reported using a computer keyboard for longer than four hours per day, while manual lifting of weights $\geq 25 \mathrm{~kg}$ in an average working day was most common in nurses. Patterns of physical activity among the "other workers" were more variable, but several such groups reported a relatively high prevalence of work with the hands above shoulder height.

Table 7 summarises reported psychosocial aspects of work. Time pressure was common in most occupational groups, but the prevalence of financial incentives to productivity was much more variable. Personal autonomy at work was lowest among "other workers". Most subjects were satisfied with their jobs, but job 
Table 4. Access to healthcare for musculoskeletal disorders.

\begin{tabular}{|c|c|c|c|c|}
\hline Country/Occupational Group & Primary care doctor & Hospital doctor & $\begin{array}{l}\text { Other } \\
\text { practitioner }\end{array}$ & Occupational health service \\
\hline \multicolumn{5}{|l|}{ Brazil } \\
\hline Nurses & Full fee & Full fee & Full fee & Through employer and external \\
\hline Office workers & Small fee & Small fee & Small fee & Through employer and external \\
\hline Other workers & Free/insured & Free/insured & Free/insured & Through employer \\
\hline \multicolumn{5}{|l|}{ Ecuador } \\
\hline Nurses & Full fee & Full fee & Full fee & Through employer or external \\
\hline Office workers & Full fee & Full fee & Full fee & External \\
\hline Other workers & Full fee & Full fee & Full fee & Through employer or external \\
\hline \multicolumn{5}{|l|}{ Colombia } \\
\hline Office workers & Free/insured & Small fee & Small fee & External \\
\hline \multicolumn{5}{|l|}{ Costa Rica } \\
\hline Nurses & Free/insured & Free/insured & Free/insured & Through employer and external \\
\hline Office workers & Free/insured & Free/insured & Free/insured & Through employer and external \\
\hline Other workers & Free/insured & Free/insured & Free/insured & Through employer and external \\
\hline \multicolumn{5}{|l|}{ Nicaragua } \\
\hline Nurses & Free/insured & Free/insured & Free/insured & External \\
\hline Office workers & Free/insured & Free/insured & Free/insured & External \\
\hline Other workers & Free/insured & Free/insured & Free/insured & External \\
\hline \multicolumn{5}{|l|}{ UK } \\
\hline Nurses & Free/insured & Free/insured & Full fee & Through employer \\
\hline Office workers & Free/insured & Free/insured & Full fee & Through employer \\
\hline Other workers & Free/insured & Free/insured & Full fee & Through employer \\
\hline \multicolumn{5}{|l|}{ Spain } \\
\hline Nurses & Free/insured & Free/insured & Free/insured & Through employer \\
\hline Office workers & Free/insured & Free/insured & Free/insured & Through employer \\
\hline \multicolumn{5}{|l|}{ Italy } \\
\hline Nurses & Free/insured & Small fee & Full fee & Through employer \\
\hline Other workers & Free/insured & Small fee & Full fee & Through employer \\
\hline \multicolumn{5}{|l|}{ Greece } \\
\hline Nurses & Free/insured & Free/Insured & Varies & No \\
\hline Office workers & Free/insured & Free/Insured & Varies & No \\
\hline Other workers & Free/insured & Free/insured & Varies & Through employer \\
\hline \multicolumn{5}{|l|}{ Estonia } \\
\hline Nurses & Free/insured & Small fee & Free/insured & Through employer and external \\
\hline Office workers & Free/insured & Small fee & Free/insured & Through employer and external \\
\hline \multicolumn{5}{|l|}{ Lebanon } \\
\hline Nurses & Full fee & Full fee & Full fee & Through employer \\
\hline Office workers & Small fee & Small fee & Small fee & Through employer \\
\hline Other workers & Small fee & Small fee & Small fee & Through employer \\
\hline \multicolumn{5}{|l|}{ Iran } \\
\hline Nurses & $\begin{array}{l}\text { Free/insured } \\
\text { or small fee }\end{array}$ & $\begin{array}{l}\text { Free/insured } \\
\text { or small fee }\end{array}$ & $\begin{array}{l}\text { Free/insured } \\
\text { or small fee }\end{array}$ & Some participants \\
\hline Office workers & $\begin{array}{l}\text { Free/insured } \\
\text { or small fee }\end{array}$ & $\begin{array}{l}\text { Free/insured } \\
\text { or small fee }\end{array}$ & $\begin{array}{l}\text { Free/insured } \\
\text { or small fee }\end{array}$ & Some participants \\
\hline \multicolumn{5}{|l|}{ Pakistan } \\
\hline Nurses & $\begin{array}{l}\text { Free/through employer } \\
\text { with a cap }\end{array}$ & $\begin{array}{l}\text { Free/through employer } \\
\text { with a cap }\end{array}$ & Full fee & No \\
\hline Office workers & $\begin{array}{l}\text { Free/through employer } \\
\text { with a cap }\end{array}$ & $\begin{array}{l}\text { Free/through employer } \\
\text { with a cap }\end{array}$ & Full fee & No \\
\hline Other workers & Free/through employer & Free/through employer & Full fee & No \\
\hline
\end{tabular}


Table 4. Cont.

\begin{tabular}{|c|c|c|c|c|}
\hline Country/Occupational Group & Primary care doctor & Hospital doctor & $\begin{array}{l}\text { Other } \\
\text { practitioner }\end{array}$ & Occupational health service \\
\hline \multicolumn{5}{|l|}{ Sri Lanka } \\
\hline Nurses & Free/insured & Free/insured & Free/insured & No \\
\hline Office workers & Free/insured & Free/insured & Free/insured & No \\
\hline Other workers (1) & Free/insured & Free/insured & Free/insured & No \\
\hline Other workers (2) & Free/insured & Free/insured & Free/insured & No \\
\hline \multicolumn{5}{|l|}{ Japan } \\
\hline Nurses & Free/insured & Free/insured & Free/insured & Through employer and external \\
\hline Office workers & Free/insured & Free/insured & Free/insured & Through employer and external \\
\hline Other workers (1) & Free/insured & Free/insured & Free/insured & Through employer and external \\
\hline Other workers (2) & Free/insured & Free/insured & Free/insured & Through employer and external \\
\hline \multicolumn{5}{|l|}{ South Africa } \\
\hline Nurses & Full fee & Small fee & Full fee & Yes \\
\hline Office workers & Full fee & Small fee & Full fee & Yes \\
\hline \multicolumn{5}{|l|}{ Australia } \\
\hline Nurses & Small fee & Small fee & Full fee & Through employer and external \\
\hline \multicolumn{5}{|l|}{ New Zealand } \\
\hline Nurses & Small fee & Free/insured & Payment varies & External and possibly through employer \\
\hline Office workers & Small fee & Free/insured & Payment varies & External and possibly through employer \\
\hline Other workers & Small fee & Free/insured & Payment varies & Through employer and external \\
\hline
\end{tabular}

doi:10.1371/journal.pone.0039820.t004

dissatisfaction was notably high in Italy, Japan and South Africa. The prevalence of perceived job insecurity ranged from $1.6 \%$ in Sri Lankan postal workers to $90.3 \%$ in Brazilian sugar cane cutters.

Table 8 shows the proportions of participants who were aware of a term such as "repetitive strain injury" ("RSI"), "work-related upper limb disorder" ("WRULD") or "cumulative trauma syndrome" ("CTS"), and also the proportions who knew someone else outside work, who had experienced musculoskeletal pain in the past 12 months. Awareness of RSI and similar terms varied widely - from $0.0 \%$ in Brazilian sugar cane cutters and $7.0 \%$ in South African office workers to $94.6 \%$ in Brazilian nurses and $95.9 \%$ in New Zealand office workers. There were also marked differences in knowledge of others with musculoskeletal complaints. For example, among food production workers in Lebanon, only $16.1 \%$ knew someone outside work with upper limb pain, whereas in telephone call centre workers in Costa Rica, the proportion was $65.9 \%$.

Table 9 presents the prevalence of potentially adverse health beliefs about back and arm pain by occupational group. These again varied substantially (more than tenfold) between occupational groups. For example, $78.6 \%$ of Greek postal workers and $77.7 \%$ of Lebanese nurses believed that low back pain is commonly caused by people's work, as compared with only $4.0 \%$ of Sri Lankan postal workers and no Brazilian sugar cane cutters; and $31.4 \%$ of Brazilian nurses and $31.0 \%$ of Brazilian office workers had pessimistic views about the prognosis of arm pain, as compared with $1.6 \%$ of nurses and office workers in Iran and $0.0 \%$ of Brazilian sugar cane cutters.

Table 10 compares the characteristics of participants in the UK who answered the questionnaire at interview and by selfadministration. Among the nurses and especially the "other workers", participation rates were higher among those invited to interview, whereas in the office workers they were slightly lower. However, there were no consistent differences in the prevalence of reported occupational activities and musculoskeletal pain according to the method of data collection.

\section{Discussion}

The CUPID study has generated substantial information which will be the subject of multiple reports. A particular strength is its use of standardised questions to collect information from participants in many different countries and cultural settings. This should provide valuable insights into the determinants of common musculoskeletal illness and associated disability, and particularly the extent of differences between countries.

The occupational groups were chosen for study with the aim that the prevalence of relevant physical tasks should differ between the three broad categories (nurses, office workers and "other workers"), but that within each of these categories, it should be broadly similar across countries. For nurses and office workers this objective was fairly well achieved, although inevitably there was some heterogeneity. For example, in some countries, nurses routinely lift and move patients, whereas in others such tasks may normally be undertaken by care assistants or patients' family members. For "other workers", there was more variation in occupational activities, reflecting the greater diversity of groups selected for study. Nevertheless, the mix of activities tended to differ from that of nurses and office workers, with a relatively high prevalence of work with the arms elevated; and apart from sales personnel in Japan, all groups of "other workers" had a high prevalence of work involving prolonged repetitive movement of the wrists or hands.

The international analysis of data is restricted to subjects aged 20-59 years at baseline, who had held their current job for at least 
Table 5. Characteristics of study sample - prevalence (\%) by occupational group.

\begin{tabular}{|c|c|c|c|c|c|c|c|c|c|c|c|c|c|}
\hline \multirow[t]{2}{*}{$\begin{array}{l}\text { Country/ } \\
\text { Occupational Group }\end{array}$} & \multirow{2}{*}{$\frac{\text { Sex }}{\text { Males }}$} & \multicolumn{4}{|c|}{ Age (years) } & \multicolumn{4}{|c|}{$\begin{array}{l}\text { Age finished full time } \\
\text { education (years) }\end{array}$} & \multirow{2}{*}{$\begin{array}{l}\begin{array}{l}\text { Years in } \\
\text { current job }\end{array} \\
>5\end{array}$} & \multicolumn{3}{|c|}{ Hours worked/week } \\
\hline & & $20-29$ & 30-39 & 40-49 & 50-59 & $<14$ & 14-16 & 17-19 & $20+$ & & $<30$ & $30-49$ & $>50$ \\
\hline \multicolumn{14}{|l|}{ Brazil } \\
\hline Nurses & 11.4 & 15.7 & 24.9 & 43.8 & 15.7 & 32.6 & 38.6 & 13.6 & 15.2 & 90.3 & 5.6 & 87.2 & 7.3 \\
\hline Office workers & 21.7 & 1.4 & 23.1 & 57.3 & 18.1 & 36.9 & 35.0 & 17.9 & 10.2 & 86.6 & 50.5 & 44.7 & 4.8 \\
\hline Other workers & 94.6 & 32.3 & 34.4 & 23.7 & 9.7 & 59.1 & 21.6 & 12.5 & 6.8 & 57.1 & 0.0 & 100.0 & 0.0 \\
\hline \multicolumn{14}{|l|}{ Ecuador } \\
\hline Nurses & 0.0 & 6.8 & 17.8 & 33.8 & 41.6 & 1.8 & 2.3 & 29.7 & 66.2 & 78.5 & 73.5 & 26.5 & 0.0 \\
\hline Office workers & 0.0 & 11.9 & 19.8 & 44.9 & 23.5 & 0.4 & 0.0 & 35.8 & 63.8 & 77.0 & 3.3 & 90.5 & 6.2 \\
\hline Other workers & 0.0 & 43.6 & 41.4 & 11.9 & 3.1 & 52.0 & 19.4 & 11.9 & 16.7 & 39.6 & 2.2 & 90.3 & 7.5 \\
\hline \multicolumn{14}{|l|}{ Colombia } \\
\hline Office workers & 37.0 & 27.2 & 44.6 & 25.0 & 3.3 & 0.0 & 6.5 & 17.4 & 76.1 & 64.1 & 26.1 & 64.1 & 9.8 \\
\hline \multicolumn{14}{|l|}{ Costa Rica } \\
\hline Nurses & 33.6 & 32.3 & 28.2 & 25.9 & 13.6 & 2.3 & 3.2 & 22.2 & 72.2 & 65.1 & 0.5 & 72.1 & 27.4 \\
\hline Office workers & 38.1 & 32.7 & 27.8 & 25.6 & 13.9 & 0.5 & 1.4 & 21.2 & 77.0 & 63.3 & 1.4 & 94.6 & 4.1 \\
\hline Other workers & 36.6 & 49.8 & 23.4 & 16.1 & 10.7 & 0.0 & 0.5 & 27.9 & 71.6 & 49.0 & 16.1 & 82.4 & 1.5 \\
\hline \multicolumn{14}{|l|}{ Nicaragua } \\
\hline Nurses & 3.2 & 7.4 & 34.0 & 37.9 & 20.6 & 0.4 & 2.5 & 10.7 & 86.4 & 88.3 & 1.1 & 91.4 & 7.5 \\
\hline Office workers & 27.4 & 33.3 & 35.1 & 22.1 & 9.5 & 0.7 & 4.6 & 7.4 & 87.4 & 57.9 & 5.3 & 93.3 & 1.4 \\
\hline Other workers & 54.8 & 51.8 & 37.1 & 7.1 & 4.1 & 9.6 & 24.4 & 35.0 & 31.0 & 21.8 & 0.0 & 100.0 & 0.0 \\
\hline \multicolumn{14}{|l|}{ UK } \\
\hline Nurses & 10.1 & 24.5 & 37.4 & 26.1 & 12.1 & 0.0 & 23.7 & 31.9 & 44.4 & 73.4 & 27.6 & 72.4 & 0.0 \\
\hline Office workers & 44.7 & 14.7 & 31.3 & 32.1 & 21.8 & 0.0 & 11.1 & 21.6 & 67.4 & 62.5 & 1.6 & 94.1 & 4.3 \\
\hline Other workers & 62.4 & 5.4 & 19.9 & 36.8 & 37.8 & 0.8 & 31.5 & 33.3 & 34.4 & 85.5 & 21.8 & 70.9 & 7.3 \\
\hline \multicolumn{14}{|l|}{ Spain } \\
\hline Nurses & 9.9 & 25.0 & 29.2 & 29.4 & 16.4 & 0.3 & 7.8 & 154 & 76.5 & 72.4 & 11.8 & 87.3 & 0.9 \\
\hline Office workers & 16.4 & 16.7 & 37.7 & 34.7 & 11.0 & 0.0 & 2.5 & 21.7 & 75.8 & 67.4 & 11.6 & 88.1 & 0.2 \\
\hline \multicolumn{14}{|l|}{ Italy } \\
\hline Nurses & 16.4 & 17.5 & 34.9 & 32.5 & 15.1 & 3.5 & 11.2 & 19.4 & 65.9 & 79.3 & 13.1 & 86.1 & 0.8 \\
\hline Other workers & 28.1 & 5.0 & 36.0 & 37.4 & 21.6 & 16.5 & 33.1 & 40.3 & 10.1 & 83.2 & 9.6 & 90.4 & 0.0 \\
\hline \multicolumn{14}{|l|}{ Greece } \\
\hline Nurses & 12.1 & 5.8 & 67.0 & 27.2 & 0.0 & 0.0 & 0.4 & 18.3 & 81.3 & 92.0 & 0.5 & 97.3 & 2.3 \\
\hline Office workers & 25.1 & 7.0 & 46.2 & 32.7 & 14.1 & 0.0 & 0.0 & 20.1 & 79.9 & 86.4 & 16.1 & 71.9 & 12.1 \\
\hline Other workers & 82.9 & 1.4 & 12.1 & 57.9 & 28.6 & 2.9 & 2.1 & 66.4 & 28.6 & 88.6 & 2.9 & 92.9 & 4.3 \\
\hline \multicolumn{14}{|l|}{ Estonia } \\
\hline Nurses & 0.5 & 15.1 & 31.3 & 26.1 & 27.5 & 0.3 & 10.3 & 46.7 & 42.7 & 70.0 & 5.8 & 86.4 & 7.8 \\
\hline Office workers & 15.3 & 17.3 & 31.2 & 27.7 & 23.8 & 0.0 & 0.0 & 20.5 & 79.5 & 66.3 & 5.0 & 89.0 & 6.0 \\
\hline \multicolumn{14}{|l|}{ Lebanon } \\
\hline Nurses & 33.7 & 57.6 & 31.0 & 9.8 & 1.6 & 0.5 & 0.0 & 4.9 & 94.6 & 48.4 & 0.0 & 97.3 & 2.7 \\
\hline Office workers & 42.4 & 20.3 & 31.4 & 30.2 & 18.0 & 0.0 & 1.2 & 15.1 & 83.7 & 70.9 & 0.0 & 85.5 & 14.5 \\
\hline Other workers & 52.6 & 53.3 & 29.9 & 12.4 & 4.4 & 26.3 & 29.2 & 29.9 & 14.6 & 47.4 & 0.0 & 70.8 & 29.2 \\
\hline \multicolumn{14}{|l|}{ Iran } \\
\hline Nurses & 18.3 & 32.5 & 46.7 & 17.9 & 2.8 & 0.0 & 0.8 & 12.2 & 87.0 & 68.7 & 0.8 & 65.9 & 33.3 \\
\hline Office workers & 35.2 & 49.5 & 34.6 & 14.8 & 1.1 & 0.5 & 0.5 & 30.8 & 68.1 & 50.0 & 1.1 & 63.7 & 35.2 \\
\hline Pakistan & & & & & & & & & & & & & \\
\hline Nurses & 25.7 & 72.2 & 23.0 & 3.7 & 1.1 & 0.0 & 4.3 & 29.0 & 66.7 & 36.4 & 0.5 & 26.7 & 72.7 \\
\hline Office workers & 82.2 & 53.9 & 34.4 & 10.6 & 1.1 & 0.0 & 1.7 & 17.4 & 80.9 & 48.0 & 1.1 & 35.0 & 63.9 \\
\hline Other workers & 100.0 & 9.9 & 22.5 & 53.6 & 14.0 & 0.9 & 7.8 & 25.1 & 66.2 & 86.9 & 16.7 & 77.5 & 5.9 \\
\hline
\end{tabular}


Table 5. Cont.

\begin{tabular}{|c|c|c|c|c|c|c|c|c|c|c|c|c|c|}
\hline \multirow[t]{2}{*}{$\begin{array}{l}\text { Country/ } \\
\text { Occupational Group }\end{array}$} & \multirow{2}{*}{$\frac{\text { Sex }}{\text { Males }}$} & \multicolumn{4}{|c|}{ Age (years) } & \multicolumn{4}{|c|}{$\begin{array}{l}\text { Age finished full time } \\
\text { education (years) }\end{array}$} & \multirow{2}{*}{$\begin{array}{l}\begin{array}{l}\text { Years in } \\
\text { current job }\end{array} \\
>5\end{array}$} & \multicolumn{3}{|c|}{ Hours worked/week } \\
\hline & & 20-29 & 30-39 & 40-49 & $50-59$ & $<14$ & $14-16$ & 17-19 & 20+ & & $<30$ & $30-49$ & $>50$ \\
\hline \multicolumn{14}{|l|}{ Sri Lanka } \\
\hline Nurses & 0.0 & 46.2 & 38.6 & 12.7 & 2.5 & 0.0 & 0.8 & 38.6 & 60.6 & 50.4 & 0.0 & 34.3 & 65.7 \\
\hline Office workers & 71.7 & 75.7 & 19.1 & 2.6 & 2.6 & 0.0 & 0.0 & 12.5 & 87.5 & 30.9 & 0.0 & 36.8 & 63.2 \\
\hline Other workers (1) & 100.0 & 0.4 & 8.4 & 46.0 & 45.2 & 3.6 & 65.2 & 28.0 & 3.2 & 81.6 & 0.0 & 21.6 & 78.4 \\
\hline Other workers (2) & 0.0 & 67.5 & 17.9 & 10.6 & 4.0 & 2.6 & 29.1 & 47.0 & 21.2 & 40.4 & 0.0 & 25.8 & 74.2 \\
\hline \multicolumn{14}{|l|}{ Japan } \\
\hline Nurses & 3.4 & 43.1 & 32.6 & 13.5 & 10.8 & 0.0 & 0.0 & 10.1 & 89.9 & 62.5 & 5.7 & 59.6 & 34.7 \\
\hline Office workers & 56.5 & 4.5 & 36.1 & 32.9 & 26.5 & 0.0 & 1.3 & 13.2 & 85.5 & 73.9 & 13.1 & 50.7 & 36.3 \\
\hline Other workers (1) & 99.6 & 20.9 & 40.4 & 27.4 & 11.3 & 0.0 & 5.7 & 65.8 & 28.5 & 78.3 & 14.3 & 15.3 & 70.5 \\
\hline Other workers (2) & 93.2 & 29.0 & 50.1 & 17.7 & 3.1 & 0.0 & 1.4 & 4.8 & 93.8 & 78.3 & 8.8 & 12.7 & 78.5 \\
\hline \multicolumn{14}{|l|}{ South Africa } \\
\hline Nurses & 3.6 & 16.2 & 31.6 & 37.2 & 15.0 & 0.0 & 0.8 & 18.0 & 81.2 & 69.6 & 0.0 & 100.0 & 0.0 \\
\hline Office workers & 32.3 & 42.8 & 28.4 & 20.5 & 8.3 & 0.4 & 11.2 & 62.3 & 26.0 & 41.9 & 0.0 & 100.0 & 0.0 \\
\hline \multicolumn{14}{|l|}{ Australia } \\
\hline Nurses & 6.8 & 13.2 & 29.6 & 29.2 & 28.0 & 0.0 & 6.8 & 31.3 & 61.8 & 57.8 & 43.1 & 48.4 & 8.5 \\
\hline \multicolumn{14}{|l|}{ New Zealand } \\
\hline Nurses & 5.6 & 8.5 & 21.5 & 35.6 & 34.5 & 0.6 & 14.7 & 37.3 & 47.5 & 75.7 & 32.2 & 62.7 & 5.1 \\
\hline Office workers & 6.2 & 4.1 & 12.4 & 40.0 & 43.4 & 0.7 & 40.7 & 49.0 & 9.7 & 71.7 & 31.7 & 64.8 & 3.5 \\
\hline Other workers & 33.6 & 18.6 & 17.7 & 31.0 & 32.7 & 0.0 & 37.2 & 46.0 & 16.8 & 54.9 & 47.3 & 51.8 & 0.9 \\
\hline
\end{tabular}

doi:10.1371/journal.pone.0039820.t005

12 months. These restrictions were set when the CUPID study was first planned, the latter because some outcomes of interest from the baseline survey, such as sickness absence in the past 12 months, would otherwise be difficult to interpret.

The questions used in the baseline and follow-up surveys were for the most part well-established, having been used successfully in previous studies. In particular, the items on mental health and somatising tendency were taken from validated instruments, and have previously demonstrated predictive validity for the incidence and persistence of musculoskeletal symptoms [7]. Similarly, the questions on fear avoidance beliefs were based on a validated questionnaire [25], and have shown predictive validity in a longitudinal study [7]. The questions on occupational physical activities have been successfully used in earlier studies $[7,13,23,24]$, and the consistency of answers with expectation (e.g. the high prevalence of prolonged keyboard use in office workers) supports their validity. There is no reliable standard against which to assess the accuracy with which subjective symptoms such as pain are reported, but the questions about pain and disability had again been used successfully in earlier studies. Moreover, the style of our questions about symptoms was similar to that of the Nordic questionnaire, which has been shown to have acceptable reliability [28].

Ensuring the accuracy with which the questionnaire was translated into local languages was a challenge. Care was taken to check the accuracy of translation by independent backtranslation to English, and this revealed a number of problems. One was the distinction between "stairs" and "flights of stairs", and despite attempts to resolve this problem, it is not certain that the term "30 flights of stairs" was always interpreted correctly. Therefore, this question will be ignored in future analyses based on the full dataset. Another difficulty arose with questions of the form
"Do you expect that your back pain will be a problem in 12 months time". In some languages this became "Do you expect your back pain will be a problem over the next 12 months". Attempts were made to correct this misunderstanding, but it is possible that they were not fully successful.

In addition, terms such as "pain" may be understood differently in different languages even though translated as closely as possible. For this reason, when comparing countries, differences in the relative frequency of pain at different anatomical sites may be particularly revealing - there should have been little ambiguity in the understanding of anatomical sites since they were depicted clearly in diagrams. Interpretation should also be assisted by the questions that were asked about associated difficulty with tasks of daily living, since these were probably understood more uniformly.

Another difficulty that had not been expected was in the use of dates. It emerged that some participants in Iran and Japan used different numbering for calendar years, and where this occurred, corrections had to be made.

Some local investigators opted to include extra questions in addition to the core questions prescribed by CUPID. However, these additions were relatively minor and generally followed after the core questions. Thus, it seems unlikely that they will have influenced answers to the core questions importantly.

Ideally, all questionnaires would have been completed in the same way (interview or self-administration) by all participants. However, this proved impractical. Some occupational groups (especially manual workers in developing countries) would have had great difficulty in answering a written questionnaire, while some employers were unwilling to release their staff for interviews. Moreover, in New Zealand, where nurses and office workers were recruited from across the country, interviews would have been prohibitively expensive. 
Table 6. Physical activities in an average working day - prevalence (\%) by occupational group.

\begin{tabular}{|c|c|c|c|c|c|c|}
\hline \multirow[t]{2}{*}{$\begin{array}{l}\text { Country/Occupational } \\
\text { Group }\end{array}$} & \multicolumn{6}{|l|}{ Activity $^{a}$} \\
\hline & $\begin{array}{l}\text { Use keyboard } \\
>4 \text { hours }\end{array}$ & $\begin{array}{l}\text { Other repeated wrist/ } \\
\text { hand movement } \\
>4 \text { hours }\end{array}$ & $\begin{array}{l}\text { Repeated elbow } \\
\text { bending }>1 \text { hour }\end{array}$ & $\begin{array}{l}\text { Hands above } \\
\text { shoulder height } \\
>1 \mathrm{hr}\end{array}$ & $\begin{array}{l}\text { Lifting } \geq 25 \mathrm{~kg} \\
\text { by hand }\end{array}$ & $\begin{array}{l}\text { Kneeling/ } \\
\text { squatting } \\
>1 \text { hour }\end{array}$ \\
\hline \multicolumn{7}{|l|}{ Brazil } \\
\hline Nurses & 9.7 & 51.9 & 68.1 & 11.9 & 49.7 & 34.1 \\
\hline Office workers & 70.8 & 70.8 & 81.5 & 12.5 & 10.3 & 13.2 \\
\hline Other workers & 0.0 & 100.0 & 100.0 & 0.0 & 0.0 & 100.0 \\
\hline \multicolumn{7}{|l|}{ Ecuador } \\
\hline Nurses & 8.2 & 82.6 & 89 & 36.1 & 68.0 & 62.6 \\
\hline Office workers & 84.0 & 78.6 & 84.8 & 39.1 & 5.3 & 16.0 \\
\hline Other workers & 11.5 & 92.1 & 95.2 & 82.4 & 21.1 & 79.3 \\
\hline \multicolumn{7}{|l|}{ Colombia } \\
\hline Office workers & 90.2 & 62.0 & 72.8 & 18.5 & 6.5 & 4.3 \\
\hline \multicolumn{7}{|l|}{ Costa Rica } \\
\hline Nurses & 10.9 & 66.4 & 82.7 & 30.9 & 63.6 & 44.1 \\
\hline Office workers & 96.0 & 76.2 & 84.8 & 19.3 & 5.4 & 9.4 \\
\hline Other workers & 99.0 & 86.3 & 88.3 & 20.5 & 4.9 & 4.9 \\
\hline \multicolumn{7}{|l|}{ Nicaragua } \\
\hline Nurses & 0.7 & 78.4 & 83.0 & 35.8 & 42.2 & 50.0 \\
\hline Office workers & 89.8 & 91.6 & 84.9 & 46.0 & 13.3 & 17.2 \\
\hline Other workers & 4.1 & 73.6 & 81.7 & 26.4 & 13.2 & 14.7 \\
\hline \multicolumn{7}{|l|}{ UK } \\
\hline Nurses & 12.8 & 44.0 & 54.9 & 8.9 & 28.4 & 18.7 \\
\hline Office workers & 88.9 & 31.1 & 27.1 & 1.3 & 4.2 & 0.5 \\
\hline Other workers & 4.1 & 81.9 & 91.2 & 51.8 & 12.2 & 9.8 \\
\hline \multicolumn{7}{|l|}{ Spain } \\
\hline Nurses & 18.9 & 59.4 & 93.7 & 52.5 & 82.2 & 70.5 \\
\hline Office workers & 96.8 & 71.0 & 91.8 & 27.4 & 2.1 & 14.8 \\
\hline \multicolumn{7}{|l|}{ Italy } \\
\hline Nurses & 4.9 & 55.4 & 80.2 & 24.6 & 60.6 & 17.0 \\
\hline Other workers & 10.1 & 84.2 & 85.6 & 29.5 & 26.6 & 4.3 \\
\hline \multicolumn{7}{|l|}{ Greece } \\
\hline Nurses & 2.7 & 71.4 & 88.8 & 29.0 & 70.1 & 30.4 \\
\hline Office workers & 87.4 & 58.8 & 74.9 & 6.0 & 7.0 & 6.5 \\
\hline Other workers & 1.4 & 83.6 & 96.4 & 65.7 & 47.1 & 22.1 \\
\hline \multicolumn{7}{|l|}{ Estonia } \\
\hline Nurses & 18.1 & 64.4 & 72.5 & 21.0 & 56.6 & 28.6 \\
\hline Office workers & 94.6 & 40.6 & 51.0 & 8.4 & 2.5 & 2.5 \\
\hline \multicolumn{7}{|l|}{ Lebanon } \\
\hline Nurses & 3.3 & 97.3 & 96.2 & 42.9 & 51.6 & 34.2 \\
\hline Office workers & 85.5 & 73.8 & 77.3 & 13.4 & 14.5 & 7.0 \\
\hline Other workers & 1.5 & 98.5 & 97.1 & 45.3 & 44.5 & 25.5 \\
\hline \multicolumn{7}{|l|}{ Iran } \\
\hline Nurses & 10.2 & 63.0 & 81.3 & 43.1 & 24.8 & 49.6 \\
\hline Office workers & 97.3 & 89.6 & 81.3 & 40.1 & 7.1 & 18.7 \\
\hline \multicolumn{7}{|l|}{ Pakistan } \\
\hline Nurses & 54.5 & 93.6 & 64.2 & 90.9 & 73.3 & 23.0 \\
\hline Office workers & 91.7 & 95.6 & 35.6 & 83.9 & 24.4 & 10.0 \\
\hline Other workers & 7.2 & 78.4 & 30.2 & 77.5 & 25.7 & 7.2 \\
\hline
\end{tabular}


Table 6. Cont.

\begin{tabular}{|c|c|c|c|c|c|c|}
\hline \multirow[t]{2}{*}{$\begin{array}{l}\text { Country/Occupational } \\
\text { Group }\end{array}$} & \multicolumn{6}{|l|}{ Activity $^{a}$} \\
\hline & $\begin{array}{l}\text { Use keyboard } \\
>4 \text { hours }\end{array}$ & $\begin{array}{l}\text { Other repeated wrist/ } \\
\text { hand movement } \\
>4 \text { hours }\end{array}$ & $\begin{array}{l}\text { Repeated elbow } \\
\text { bending }>1 \text { hour }\end{array}$ & $\begin{array}{l}\text { Hands above } \\
\text { shoulder height } \\
>1 \mathrm{hr}\end{array}$ & $\begin{array}{l}\text { Lifting } \geq 25 \mathrm{~kg} \\
\text { by hand }\end{array}$ & $\begin{array}{l}\text { Kneeling/ } \\
\text { squatting } \\
>1 \text { hour }\end{array}$ \\
\hline \multicolumn{7}{|l|}{ Sri Lanka } \\
\hline Nurses & 1.3 & 60.6 & 43.2 & 14.4 & 36.9 & 9.3 \\
\hline Office workers & 100.0 & 94.7 & 72.4 & 11.8 & 25.7 & 17.1 \\
\hline Other workers (1) & 0.0 & 95.6 & 95.6 & 95.6 & 0.0 & 0.0 \\
\hline Other workers (2) & 0.7 & 86.1 & 60.9 & 25.2 & 4.6 & 29.1 \\
\hline \multicolumn{7}{|l|}{ Japan } \\
\hline Nurses & 23.5 & 23.8 & 72.8 & 12.5 & 66.9 & 48.5 \\
\hline Office workers & 89.0 & 12.9 & 22.6 & 1.6 & 3.2 & 2.3 \\
\hline Other workers (1) & 2.4 & 32.8 & 77.8 & 33.7 & 83.3 & 52.3 \\
\hline Other workers (2) & 27.9 & 10.1 & 30.1 & 4.2 & 9.3 & 12.1 \\
\hline \multicolumn{7}{|l|}{ South Africa } \\
\hline Nurses & 11.3 & 76.1 & 85.0 & 53.4 & 80.2 & 26.3 \\
\hline Office workers & 100.0 & 76.9 & 78.6 & 26.2 & 4.8 & 1.3 \\
\hline \multicolumn{7}{|l|}{ Australia } \\
\hline Nurses & 25.6 & 32.8 & 47.6 & 8.4 & 25.2 & 15.2 \\
\hline \multicolumn{7}{|l|}{ New Zealand } \\
\hline Nurses & 26.6 & 32.8 & 42.4 & 4.0 & 31.6 & 14.1 \\
\hline Office workers & 91.7 & 40.0 & 44.8 & 0.7 & 2.1 & 0.0 \\
\hline Other workers & 10.6 & 87.6 & 91.2 & 34.5 & 51.3 & 5.3 \\
\hline
\end{tabular}

doi:10.1371/journal.pone.0039820.t006

To explore whether the two methods of answering the questionnaire might lead to systematic differences in answers, we therefore elected to interview a random subset of UK participants while collecting data from the remainder by self-administration. Comparison of responses using the two approaches (Table 10) suggests that no major bias will have occurred as a consequence using both interviews and self-administration. However, if appropriate, method of data collection can be taken into account in statistical analyses.

Participation rates among subjects eligible for study were mostly high, but were less than $50 \%$ in five occupational groups (Table 2). We have no reason to expect that those who elected to take part were importantly unrepresentative in the prevalence of pain and its associations with risk factors. However, in future work it may be appropriate to carry out sensitivity analyses, excluding the occupational groups with the lowest response rates. The incomplete response to the baseline questionnaire will be less of a concern in longitudinal analyses based on the follow-up questionnaire.

The numbers of participants by occupational group that were suitable for analysis ranged from 92 to 1018 with a mean of 264 . At the outset, our aim was to recruit at least 200 subjects in each group, and this was for the most part achieved (only 7 groups provided fewer than 150 subjects). Furthermore, the occupational groups studied varied substantially in their employment conditions (Table 3), access to healthcare (Table 4), and prevalence of psychosocial risk factors (Tables 7, 8, and 9). When exploring possible reasons for differences in the prevalence of pain and disability between occupational groups, it will be important to investigate these group-level characteristics as well as individuallevel risk factors such as mental health and somatising tendency. The heterogeneity in their distribution should enhance statistical power to address their impact.

As might be expected, the demographic constitution of occupational groups also varied. In particular, many of the samples of nurses were largely or completely female, whereas some groups of "other workers" were all men. This reflects the nature of the occupations of interest. However, it should not be a major problem in interpretation of comparisons since there were an adequate number of occupational groups with a fairly even distribution of sex and age. Moreover, the occurrence of common musculoskeletal complaints appears not to vary greatly between men and women or between older and younger adults of working age $[13,23,24]$.

In summary, the CUPID study is a major resource for the investigation of cultural and psychological determinants of common musculoskeletal disorders and associated disability. Although the data collected have inevitable limitations, the large differences in psychosocial risk factors (including knowledge and beliefs about MSDs) between occupational groups carrying out similar physical tasks in different countries should allow the study hypothesis to be addressed effectively. It will also allow exploration of differences in patterns of musculoskeletal complaint between the three categories of occupation examined, and the consistency of these differences across countries. 
Table 7. Psychosocial aspects of work - prevalence (\%) by occupational group.

\begin{tabular}{|c|c|c|c|c|c|c|}
\hline Country/Occupational Group & Incentives $^{\mathrm{a}}$ & $\begin{array}{l}\text { Time } \\
\text { pressure }\end{array}$ & $\begin{array}{l}\text { Lack of } \\
\text { choice }^{c}\end{array}$ & $\begin{array}{l}\text { Lack of } \\
\text { support }^{d}\end{array}$ & $\begin{array}{l}\text { Job } \\
\text { dissatisfaction }\end{array}$ & $\begin{array}{l}\text { Perceived job } \\
\text { insecurity }^{f}\end{array}$ \\
\hline \multicolumn{7}{|l|}{ Brazil } \\
\hline Nurses & 25.4 & 65.4 & 13.5 & 4.9 & 7.6 & 20.0 \\
\hline Office workers & 13.9 & 49.8 & 9.6 & 11.7 & 19.2 & 24.9 \\
\hline Other workers & 100.0 & 96.8 & 96.8 & 2.2 & 5.4 & 90.3 \\
\hline \multicolumn{7}{|l|}{ Ecuador } \\
\hline Nurses & 29.2 & 69.4 & 39.7 & 51.6 & 1.8 & 30.1 \\
\hline Office workers & 37.0 & 63.4 & 10.7 & 63.4 & 4.5 & 29.2 \\
\hline Other workers & 45.8 & 65.2 & 52.0 & 63.4 & 11.5 & 50.7 \\
\hline \multicolumn{7}{|l|}{ Colombia } \\
\hline Office workers & 50.0 & 56.5 & 2.2 & 40.2 & 2.2 & 25.0 \\
\hline \multicolumn{7}{|l|}{ Costa Rica } \\
\hline Nurses & 48.2 & 92.7 & 24.5 & 36.8 & 12.7 & 17.7 \\
\hline Office workers & 63.2 & 77.6 & 8.1 & 28.7 & 10.8 & 18.4 \\
\hline Other workers & 67.8 & 77.6 & 50.7 & 29.3 & 17.1 & 26.3 \\
\hline \multicolumn{7}{|l|}{ Nicaragua } \\
\hline Nurses & 16.0 & 72.3 & 10.3 & 41.5 & 13.5 & 22.7 \\
\hline Office workers & 26.0 & 80.0 & 19.3 & 43.2 & 9.5 & 23.2 \\
\hline Other workers & 86.8 & 60.9 & 37.1 & 41.1 & 6.1 & 31.0 \\
\hline \multicolumn{7}{|l|}{ UK } \\
\hline Nurses & 6.2 & 75.1 & 9.7 & 10.1 & 14.8 & 17.9 \\
\hline Office workers & 0.5 & 76.6 & 6.8 & 7.9 & 7.9 & 5.0 \\
\hline Other workers & 19.2 & 79.5 & 37.8 & 17.4 & 15.5 & 35.8 \\
\hline \multicolumn{7}{|l|}{ Spain } \\
\hline Nurses & 21.0 & 80.1 & 19.9 & 77.7 & 12.0 & 16.5 \\
\hline Office workers & 26.3 & 54.3 & 32.4 & 78.5 & 6.6 & 13.7 \\
\hline \multicolumn{7}{|l|}{ Italy } \\
\hline Nurses & 11.6 & 80.6 & 13.2 & 8.2 & 17.4 & 21.5 \\
\hline Other workers & 19.4 & 82.7 & 53.2 & 34.5 & 51.8 & 41.7 \\
\hline \multicolumn{7}{|l|}{ Greece } \\
\hline Nurses & 6.3 & 97.3 & 8.9 & 14.7 & 33.9 & 29.0 \\
\hline Office workers & 6.5 & 83.4 & 1.5 & 9.5 & 7.0 & 12.6 \\
\hline Other workers & 2.1 & 97.9 & 15.0 & 40.7 & 18.6 & 17.9 \\
\hline \multicolumn{7}{|l|}{ Estonia } \\
\hline Nurses & 7.8 & 66.6 & 23.7 & 27.0 & 6.2 & 14.3 \\
\hline Office workers & 4.0 & 64.4 & 2.0 & 8.4 & 5.9 & 23.3 \\
\hline \multicolumn{7}{|l|}{ Lebanon } \\
\hline Nurses & 81.0 & 95.1 & 6.0 & 6.5 & 20.1 & 38.6 \\
\hline Office workers & 11.6 & 75.6 & 7.6 & 12.2 & 16.9 & 25.0 \\
\hline Other workers & 75.9 & 76.6 & 29.9 & 6.6 & 16.8 & 41.6 \\
\hline \multicolumn{7}{|l|}{ Iran } \\
\hline Nurses & 28.9 & 90.2 & 24.8 & 23.6 & 29.3 & 54.9 \\
\hline Office workers & 29.7 & 74.2 & 18.7 & 26.9 & 26.4 & 66.5 \\
\hline \multicolumn{7}{|l|}{ Pakistan } \\
\hline Nurses & 62.0 & 96.3 & 40.1 & 7.5 & 9.1 & 56.7 \\
\hline Office workers & 68.3 & 96.1 & 45.6 & 7.8 & 7.8 & 53.9 \\
\hline Other workers & 11.7 & 95.0 & 68.0 & 7.7 & 9.0 & 14.9 \\
\hline \multicolumn{7}{|l|}{ Sri Lanka } \\
\hline Nurses & 56.8 & 91.5 & 5.9 & 7.2 & 4.7 & 11.4 \\
\hline Office workers & 18.4 & 87.5 & 10.5 & 5.3 & 8.6 & 43.4 \\
\hline
\end{tabular}


Table 7. Cont.

\begin{tabular}{|c|c|c|c|c|c|c|}
\hline Country/Occupational Group & Incentives $^{\mathbf{a}}$ & $\begin{array}{l}\text { Time } \\
\text { pressure }^{\mathbf{b}}\end{array}$ & $\begin{array}{l}\text { Lack of } \\
\text { choice }^{c}\end{array}$ & $\begin{array}{l}\text { Lack of } \\
\text { support }\end{array}$ & $\begin{array}{l}\text { Job } \\
\text { dissatisfaction }\end{array}$ & $\begin{array}{l}\text { Perceived job } \\
\text { insecurity }^{f}\end{array}$ \\
\hline Other workers (1) & 100.0 & 100.0 & 0.0 & 0.0 & 2.8 & 1.6 \\
\hline Other workers (2) & 95.4 & 94.0 & 17.2 & 11.9 & 4.0 & 33.8 \\
\hline \multicolumn{7}{|l|}{ Japan } \\
\hline Nurses & 4.4 & 63.0 & 20.9 & 5.7 & 44.4 & 41.2 \\
\hline Office workers & 3.2 & 35.5 & 18.1 & 12.6 & 70.3 & 43.5 \\
\hline Other workers (1) & 30.7 & 81.1 & 28.0 & 20.1 & 41.9 & 64.5 \\
\hline Other workers (2) & 9.9 & 41.4 & 4.5 & 5.4 & 69.6 & 49.6 \\
\hline \multicolumn{7}{|l|}{ South Africa } \\
\hline Nurses & 21.1 & 80.2 & 23.1 & 13.8 & 34.8 & 29.6 \\
\hline Office workers & 52 & 95.2 & 37.6 & 21.8 & 43.7 & 66.4 \\
\hline \multicolumn{7}{|l|}{ Australia } \\
\hline Nurses & 4.4 & 66.8 & 3.2 & 7.6 & 8.8 & 10.8 \\
\hline \multicolumn{7}{|l|}{ New Zealand } \\
\hline Nurses & 1.7 & 58.2 & 9.0 & 8.5 & 13.6 & 22.0 \\
\hline Office workers & 2.1 & 58.6 & 4.8 & 18.6 & 8.3 & 17.9 \\
\hline Other workers & 34.5 & 80.5 & 23.9 & 14.2 & 8.8 & 20.4 \\
\hline
\end{tabular}

${ }^{\mathrm{a}}$ Either a) piecework or b) payment of a bonus if more than an agreed number of articles/tasks are finished in a day.

bEither a) a target number of articles or tasks to be finished in the day or b) working under pressure to complete tasks by a fixed time.

'Choice seldom or never in all of: a) how work is done, b) what is done at work, and c) work timetable and breaks.

${ }^{d}$ Support from colleagues or supervisor/manager seldom or never.

eDissatisfied or very dissatisfied overall.

${ }^{f}$ Feel job would be rather unsafe or very unsafe if off work for three months with significant illness.

doi:10.1371/journal.pone.0039820.t007 
Table 8. Awareness of repetitive strain injury (RSI) work related upper limb disorder (WRULD) or cumulative trauma syndrome (CTS) - prevalence (\%) by occupational group.

\begin{tabular}{|c|c|c|c|c|c|}
\hline \multirow{3}{*}{ Country/Occupational Group } & \multicolumn{5}{|c|}{ Proportion (\%) of participants reporting awareness of } \\
\hline & \multirow[t]{2}{*}{$\begin{array}{l}\text { RSI, WRULD } \\
\text { or CTS }\end{array}$} & \multicolumn{4}{|c|}{ Someone outside work with pain in past 12 months in } \\
\hline & & Low back & Neck & Upper limb & Knee \\
\hline \multicolumn{6}{|l|}{ Brazil } \\
\hline Nurses & 94.6 & 62.7 & 49.2 & 53.0 & 55.1 \\
\hline Office workers & 94.3 & 60.9 & 49.1 & 52.7 & 50.2 \\
\hline Other workers & 0.0 & 60.2 & 12.9 & 36.6 & 14.0 \\
\hline \multicolumn{6}{|l|}{ Ecuador } \\
\hline Nurses & 52.1 & 42.9 & 34.7 & 30.1 & 42.5 \\
\hline Office workers & 28.0 & 50.6 & 46.1 & 37.0 & 42.4 \\
\hline Other workers & 24.2 & 48.0 & 27.3 & 39.2 & 32.2 \\
\hline \multicolumn{6}{|l|}{ Colombia } \\
\hline Office workers & 43.5 & 40.2 & 34.8 & 32.6 & 39.1 \\
\hline \multicolumn{6}{|l|}{ Costa Rica } \\
\hline Nurses & 54.1 & 55.9 & 43.6 & 42.7 & 46.4 \\
\hline Office workers & 26.9 & 61.0 & 49.3 & 48.4 & 45.7 \\
\hline Other workers & 36.1 & 74.6 & 65.9 & 65.9 & 61.5 \\
\hline \multicolumn{6}{|l|}{ Nicaragua } \\
\hline Nurses & 56.0 & 71.6 & 57.8 & 58.2 & 62.8 \\
\hline Office workers & 34.0 & 60.4 & 54.0 & 51.2 & 48.8 \\
\hline Other workers & 29.4 & 41.6 & 28.4 & 31.5 & 26.9 \\
\hline \multicolumn{6}{|l|}{ UK } \\
\hline Nurses & 76.3 & 59.1 & 30.0 & 35.0 & 41.2 \\
\hline Office workers & 93.7 & 60 & 31.8 & 33.4 & 42.6 \\
\hline Other workers & 47.9 & 42.5 & 21.0 & 26.7 & 35.0 \\
\hline \multicolumn{6}{|l|}{ Spain } \\
\hline Nurses & 67.9 & 82.6 & 73.1 & 49.8 & 55.9 \\
\hline Office workers & 59.8 & 82.9 & 80.2 & 45.3 & 50.6 \\
\hline \multicolumn{6}{|l|}{ Italy } \\
\hline Nurses & 84.7 & 82.3 & 75.6 & 56.0 & 55.4 \\
\hline Other workers & 77.0 & 69.8 & 66.9 & 54.0 & 51.1 \\
\hline \multicolumn{6}{|l|}{ Greece } \\
\hline Nurses & 21.4 & 82.6 & 62.5 & 56.3 & 50.4 \\
\hline Office workers & 24.6 & 81.4 & 68.3 & 64.8 & 51.3 \\
\hline Other workers & 15.7 & 70.7 & 50 & 43.6 & 36.4 \\
\hline \multicolumn{6}{|l|}{ Estonia } \\
\hline Nurses & 66.6 & 69.0 & 55.3 & 46.9 & 57.1 \\
\hline Office workers & 49.5 & 65.8 & 59.4 & 47.0 & 51.5 \\
\hline \multicolumn{6}{|l|}{ Lebanon } \\
\hline Nurses & 67.9 & 70.1 & 58.2 & 39.1 & 57.6 \\
\hline Office workers & 67.4 & 56.4 & 40.7 & 36.6 & 32.6 \\
\hline Other workers & 34.3 & 38.7 & 27.7 & 16.1 & 29.2 \\
\hline \multicolumn{6}{|l|}{ Iran } \\
\hline Nurses & 45.5 & 76.8 & 53.3 & 59.3 & 69.5 \\
\hline Office workers & 25.3 & 67.0 & 46.7 & 54.4 & 63.2 \\
\hline \multicolumn{6}{|l|}{ Pakistan } \\
\hline Nurses & 36.9 & 44.4 & 23.5 & 31.0 & 52.4 \\
\hline Office workers & 17.8 & 39.4 & 15.0 & 20 & 41.1 \\
\hline Other workers & 32.4 & 30.6 & 19.8 & 18.9 & 26.6 \\
\hline
\end{tabular}


Table 8. Cont.

\begin{tabular}{|c|c|c|c|c|c|}
\hline \multirow{3}{*}{ Country/Occupational Group } & \multicolumn{5}{|c|}{ Proportion (\%) of participants reporting awareness of } \\
\hline & \multirow[t]{2}{*}{$\begin{array}{l}\text { RSI, WRULD } \\
\text { or CTS }\end{array}$} & \multicolumn{4}{|c|}{ Someone outside work with pain in past 12 months in } \\
\hline & & Low back & Neck & Upper limb & Knee \\
\hline \multicolumn{6}{|l|}{ Sri Lanka } \\
\hline Nurses & 48.3 & 53.0 & 40.3 & 45.8 & 61.0 \\
\hline Office workers & 51.3 & 45.4 & 36.8 & 37.5 & 47.4 \\
\hline Other workers (1) & 82.4 & 57.2 & 27.6 & 36.0 & 57.2 \\
\hline Other workers (2) & 36.4 & 37.1 & 20.5 & 25.2 & 45.0 \\
\hline \multicolumn{6}{|l|}{ Japan } \\
\hline Nurses & 72.3 & 59.5 & 27.4 & 35.8 & 33.6 \\
\hline Office workers & 69.4 & 53.5 & 28.7 & 33.5 & 35.8 \\
\hline Other workers (1) & 35.9 & 51.6 & 17.5 & 22.5 & 20.5 \\
\hline Other workers (2) & 70.7 & 60.8 & 23.4 & 27.0 & 26.8 \\
\hline \multicolumn{6}{|l|}{ South Africa } \\
\hline Nurses & 47.0 & 51.4 & 36.4 & 34.8 & 53.8 \\
\hline Office workers & 7.0 & 55.0 & 38.4 & 39.3 & 40.2 \\
\hline \multicolumn{6}{|l|}{ Australia } \\
\hline Nurses & 78.0 & 71.6 & 49.2 & 49.6 & 53.2 \\
\hline \multicolumn{6}{|l|}{ New Zealand } \\
\hline Nurses & 84.7 & 72.3 & 53.1 & 58.2 & 57.6 \\
\hline Office workers & 95.9 & 64.1 & 44.8 & 47.6 & 54.5 \\
\hline Other workers & 86.7 & 46.9 & 27.4 & 37.2 & 42.5 \\
\hline
\end{tabular}

doi:10.1371/journal.pone.0039820.t008 
Table 9. Adverse health beliefs regarding low back and arm pain - prevalence (\%) by occupational group.

\begin{tabular}{|c|c|c|c|c|c|c|}
\hline \multirow[b]{2}{*}{$\begin{array}{l}\text { Country/ } \\
\text { Occupational Group }\end{array}$} & \multirow{2}{*}{$\begin{array}{l}\text { Low back pain } \\
\text { Commonly caused } \\
\text { by people's work }^{\text {a }}\end{array}$} & \multirow[b]{2}{*}{$\begin{array}{l}\text { Physical activity } \\
\text { is harmful }^{\mathbf{b}}\end{array}$} & \multirow[b]{2}{*}{$\begin{array}{l}\text { Poor } \\
\text { prognosis }\end{array}$} & \multirow{2}{*}{$\begin{array}{l}\text { Arm pain } \\
\text { Commonly caused } \\
\text { by people's work }^{\mathrm{a}}\end{array}$} & \multirow[b]{2}{*}{$\begin{array}{l}\text { Physical activity } \\
\text { is harmful }^{\mathbf{b}}\end{array}$} & \multirow[b]{2}{*}{$\begin{array}{l}\text { Poor } \\
\text { prognosis }\end{array}$} \\
\hline & & & & & & \\
\hline \multicolumn{7}{|l|}{ Brazil } \\
\hline Nurses & 25.9 & 5.9 & 29.7 & 31.9 & 7.0 & 31.4 \\
\hline Office workers & 32.7 & 7.5 & 31.3 & 42.7 & 6.0 & 31.0 \\
\hline Other workers & 0.0 & 1.1 & 0.0 & 0.0 & 1.1 & 0.0 \\
\hline \multicolumn{7}{|l|}{ Ecuador } \\
\hline Nurses & 53.9 & 25.1 & 20.5 & 52.1 & 18.7 & 20.5 \\
\hline Office workers & 37.9 & 18.9 & 10.7 & 33.7 & 16.0 & 9.9 \\
\hline Other workers & 77.1 & 36.1 & 4.0 & 76.2 & 27.3 & 5.3 \\
\hline \multicolumn{7}{|l|}{ Colombia } \\
\hline Office workers & 12.0 & 1.1 & 13.0 & 13.0 & 1.1 & 13.0 \\
\hline \multicolumn{7}{|l|}{ Costa Rica } \\
\hline Nurses & 30.0 & 10.9 & 17.7 & 35.0 & 10.5 & 19.1 \\
\hline Office workers & 13.9 & 4.0 & 24.2 & 11.7 & 2.7 & 22.0 \\
\hline Other workers & 16.1 & 2.9 & 25.9 & 18.0 & 2.0 & 21.5 \\
\hline \multicolumn{7}{|l|}{ Nicaragua } \\
\hline Nurses & 36.2 & 23.8 & 15.2 & 35.5 & 21.3 & 14.5 \\
\hline Office workers & 29.1 & 11.9 & 9.5 & 32.3 & 12.6 & 9.1 \\
\hline Other workers & 38.1 & 22.3 & 10.7 & 36.5 & 16.8 & 8.6 \\
\hline \multicolumn{7}{|l|}{ UK } \\
\hline Nurses & 23.7 & 9.3 & 5.8 & 15.2 & 3.5 & 2.7 \\
\hline Office workers & 9.2 & 2.9 & 4.7 & 10.8 & 1.3 & 3.2 \\
\hline Other workers & 25.6 & 10.4 & 8.8 & 20.7 & 5.2 & 5.7 \\
\hline \multicolumn{7}{|l|}{ Spain } \\
\hline Nurses & 46.8 & 23.8 & 28.2 & 36.1 & 13.8 & 18.3 \\
\hline Office workers & 22.4 & 15.5 & 22.1 & 19.6 & 9.6 & 15.3 \\
\hline \multicolumn{7}{|l|}{ Italy } \\
\hline Nurses & 34.1 & 3.2 & 6.9 & 24.1 & 0.9 & 4.5 \\
\hline Other workers & 36.0 & 7.9 & 15.8 & 40.3 & 3.6 & 16.5 \\
\hline \multicolumn{7}{|l|}{ Greece } \\
\hline Nurses & 73.2 & 49.1 & 14.7 & 68.3 & 33.5 & 12.9 \\
\hline Office workers & 40.2 & 31.2 & 10.6 & 44.2 & 18.6 & 12.6 \\
\hline Other workers & 78.6 & 68.6 & 20.0 & 76.4 & 47.1 & 12.9 \\
\hline \multicolumn{7}{|l|}{ Estonia } \\
\hline Nurses & 27.5 & 9.2 & 7.5 & 25.9 & 5.9 & 5.9 \\
\hline Office workers & 15.8 & 2.5 & 11.4 & 21.3 & 0.5 & 10.9 \\
\hline \multicolumn{7}{|l|}{ Lebanon } \\
\hline Nurses & 77.7 & 43.5 & 27.2 & 62.5 & 23.9 & 9.8 \\
\hline Office workers & 36.6 & 24.4 & 15.1 & 36.0 & 11.0 & 7.6 \\
\hline Other workers & 66.4 & 77.4 & 14.6 & 59.9 & 57.7 & 6.6 \\
\hline \multicolumn{7}{|l|}{ Iran } \\
\hline Nurses & 31.7 & 11 & 2.8 & 24.8 & 4.1 & 1.6 \\
\hline Office workers & 24.2 & 12.1 & 4.9 & 22.0 & 2.7 & 1.6 \\
\hline \multicolumn{7}{|l|}{ Pakistan } \\
\hline Nurses & 51.9 & 50.3 & 5.9 & 47.1 & 26.2 & 4.8 \\
\hline Office workers & 54.4 & 43.3 & 3.9 & 38.9 & 29.4 & 1.7 \\
\hline Other workers & 40.5 & 31.5 & 5.9 & 36.9 & 28.4 & 6.3 \\
\hline
\end{tabular}


Table 9. Cont.

\begin{tabular}{|c|c|c|c|c|c|c|}
\hline \multirow[b]{2}{*}{$\begin{array}{l}\text { Country/ } \\
\text { Occupational Group }\end{array}$} & \multirow{2}{*}{$\begin{array}{l}\text { Low back pain } \\
\text { Commonly caused } \\
\text { by people's work }^{\text {a }}\end{array}$} & \multirow[b]{2}{*}{$\begin{array}{l}\text { Physical activity } \\
\text { is harmful }{ }^{\mathbf{b}}\end{array}$} & \multirow[b]{2}{*}{$\begin{array}{l}\text { Poor } \\
\text { prognosis }\end{array}$} & \multirow{2}{*}{$\begin{array}{l}\text { Arm pain } \\
\text { Commonly caused } \\
\text { by people's work }^{\text {a }}\end{array}$} & \multirow[b]{2}{*}{$\begin{array}{l}\text { Physical activity } \\
\text { is harmful }^{\mathrm{b}}\end{array}$} & \multirow[b]{2}{*}{$\begin{array}{l}\text { Poor } \\
\text { prognosis }\end{array}$} \\
\hline & & & & & & \\
\hline \multicolumn{7}{|l|}{ Sri Lanka } \\
\hline Nurses & 5.9 & 6.4 & 9.3 & 9.7 & 3.0 & 11.4 \\
\hline Office workers & 13.8 & 10.5 & 4.6 & 19.7 & 4.6 & 3.9 \\
\hline Other workers (1) & 4.0 & 36.0 & 10.4 & 3.6 & 11.2 & 8.0 \\
\hline Other workers (2) & 20.5 & 9.9 & 7.3 & 20.5 & 6.0 & 6.0 \\
\hline \multicolumn{7}{|l|}{ Japan } \\
\hline Nurses & 46.6 & 14.7 & 18.2 & 24.3 & 5.7 & 9.3 \\
\hline Office workers & 16.5 & 19.7 & 14.2 & 11.6 & 9.0 & 7.4 \\
\hline Other workers (1) & 47.2 & 25.6 & 21.8 & 33.2 & 11.7 & 10.1 \\
\hline Other workers (2) & 21.4 & 23.7 & 17.5 & 12.4 & 16.1 & 6.5 \\
\hline \multicolumn{7}{|l|}{ South Africa } \\
\hline Nurses & 37.7 & 5.3 & 7.7 & 36.0 & 3.6 & 6.1 \\
\hline Office workers & 24.9 & 6.6 & 4.8 & 22.7 & 3.1 & 3.5 \\
\hline \multicolumn{7}{|l|}{ Australia } \\
\hline Nurses & 19.2 & 2.8 & 6.8 & 12.4 & 2.4 & 2.4 \\
\hline \multicolumn{7}{|l|}{ New Zealand } \\
\hline Nurses & 20.3 & 2.8 & 2.3 & 11.9 & 1.1 & 4.0 \\
\hline Office workers & 6.2 & 2.1 & 2.8 & 9.0 & 2.1 & 4.1 \\
\hline Other workers & 21.2 & 14.2 & 6.2 & 29.2 & 12.4 & 5.3 \\
\hline
\end{tabular}

${ }^{a}$ Completely agree that such pain is commonly caused by people's work.

${ }^{b}$ Completely agree that for someone with such pain, a) physical activity should be avoided as it might cause harm, and b) rest is needed to get better.

${ }^{c}$ Completely agree that for someone with such pain, rest is needed to get better, and completely disagree that such problems usually get better within three months. doi:10.1371/journal.pone.0039820.t009

Table 10. Comparison of UK participants who provided information by interview and by self-administered questionnaire.

\begin{tabular}{|c|c|c|c|c|c|c|}
\hline & \multicolumn{2}{|l|}{ Nurses } & \multicolumn{2}{|c|}{ Office workers } & \multicolumn{2}{|c|}{ Other workers } \\
\hline & Interview & $\begin{array}{l}\text { Self-administered } \\
\text { questionnaire }\end{array}$ & Interview & $\begin{array}{l}\text { Self-administered } \\
\text { questionnaire }\end{array}$ & Interview & $\begin{array}{l}\text { Self-administered } \\
\text { questionnaire }\end{array}$ \\
\hline Number selected & 190 & 500 & 200 & 851 & 240 & 1329 \\
\hline Number (\%) participated & $91(48)$ & $199(40)$ & $88(44)$ & $388(46)$ & $122(51)$ & $320(24)$ \\
\hline Number of subjects analysed & 78 & 179 & 66 & 314 & 110 & 276 \\
\hline \multicolumn{7}{|l|}{$\begin{array}{l}\text { Prevalence }(\%) \text { of activities in an } \\
\text { average working day }\end{array}$} \\
\hline Use keyboard $>4 \mathrm{hr}$ & 6.4 & 15.6 & 84.9 & 89.8 & 1.8 & 5.1 \\
\hline Other repeated wrist/hand movement $>4 \mathrm{hr}$ & 46.2 & 43.0 & 22.7 & 32.8 & 86.4 & 80.1 \\
\hline Repeated elbow bending $>1 \mathrm{hr}$ & 60.3 & 52.5 & 13.6 & 29.9 & 96.4 & 89.1 \\
\hline Hands above shoulder height $>1 \mathrm{hr}$ & 7.7 & 9.5 & 1.5 & 1.3 & 55.5 & 50.4 \\
\hline Lifting $\geq 25 \mathrm{~kg}$ by hand & 28.2 & 28.5 & 9.1 & 3.2 & 12.7 & 12.0 \\
\hline Kneeling/squatting $>1 \mathrm{hr}$ & 21.8 & 17.3 & 1.5 & 0.3 & 15.5 & 7.6 \\
\hline \multicolumn{7}{|l|}{ Prevalence $(\%)$ of pain in past month } \\
\hline Low back & 26.9 & 36.3 & 28.8 & 26.8 & 34.6 & 34.4 \\
\hline Neck & 14.1 & 20.1 & 21.2 & 22.9 & 20.9 & 20.7 \\
\hline Shoulder & 9.0 & 21.8 & 21.2 & 20.7 & 33.6 & 31.2 \\
\hline Elbow & 2.6 & 2.8 & 12.1 & 8.0 & 14.6 & 15.2 \\
\hline Wrist/hand & 14.1 & 15.6 & 19.7 & 17.5 & 24.6 & 21.7 \\
\hline Knee & 12.8 & 18.4 & 27.3 & 22.3 & 21.8 & 24.6 \\
\hline
\end{tabular}

doi:10.1371/journal.pone.0039820.t010 


\section{Supporting Information}

\section{Appendix S1 Committees which provided ethical ap- proval for the cupid study. (DOCX)}

\section{Appendix S2 Baseline questionnaire. (DOCX)}

\section{Appendix S3 Follow-up questionnaire. (DOCX)}

\section{Acknowledgments}

We thank: Pietro Muñoz, Patricio Oyos, Gonzalo Albuja, María Belduma and Francisco Lara for their assistance with data collection in Ecuador; Patrica Monge, Melania Chaverrri and Freddy Brenes, who helped with data collection in Costa Rica; Aurora Aragón, Alberto Berríos, Samaria Balladares and Martha Martínez who helped with data collection in Nicaragua; Alfredo José Jirón who assisted with data entry in Nicaragua; Catalina Torres for translation and piloting of the questionnaire in Spain; Ben and Marie Carmen Coggon for back translation of the Spanish questionnaire; Cynthia Alcantara, Xavier Orpella, Josep Anton Gonzalez, Joan Bas, Pilar Peña, Elena Brunat, Vicente San José, Anna Sala March, Anna Marquez, Josefina Lorente, Cristina Oliva, Montse Vergara and Eduard Gaynés for their assistance with data collection in Spain; Natale Battevi, Lorenzo Bordini, Marco Conti and Luciano Riboldi who carried out data collection in Italy; Paul Maurice Conway for back translation of the Italian questionnaire; Tiina Freimann, who helped with data collection

\section{References}

1. Lötters F, Burdorf A, Kuiper J, Miedema H (2003) Model for the workrelatedness of low-back pain. Scand J Work Environ Health 29: 431-40.

2. Palmer KT, Smedley J (2007) Work relatedness of chronic neck pain with physical findings - a systematic review. Scand J Work Environ Health 33: 16591.

3. Palmer KT (2011) Carpal tunnel syndrome: the role of occupational factors. Best Pract Res Clin Rheumatol 25: 15-29.

4. Palmer KT, Harris EC, Coggon D (2007) Compensating occupationally related tenosynovitis and epicondylitis: a literature review. Occup Med 57: 67-74.

5. Linton SJ (2000) A review of psychological risk factors in back and neck pain. Spine 25: 1148-56.

6. Macfarlane GJ, Hunt IM, Silman AJ (2000) Role of mechanical and psychosocial factors in the onset of forearm pain: prospective population based study. Br Med J 321: 676-9.

7. Palmer KT, Reading I, Linaker C, Calnan M, Coggon D (2008) Populationbased cohort study of incident and persistent arm pain: role of mental health, self-rated health and health beliefs. Pain 136: 30-37.

8. Macfarlane GJ, Pallewatte N, Paudyal P, Biyth FM, Coggon D, et al. (2009) Evaluation of work-related psychosocial factors and regional musculoskeletal pain: result from a EULAR Task Force. Ann Rheum Dis 68: 885-91.

9. Palmer K, Calnan M, Wainwright D, Poole J, O’Neill C, et al. (2005) Disabling musculoskeletal pain and its relation to somatization: A community-based postal survey. Occup Med 55: 612-617.

10. Clinical Standards Advisory Group (1994) Epidemiology review: the epidemiology and cost of back pain. London: HMSO.

11. Gun RT (1990) The incidence and distribution of RSI in South Australia 1980 81 and 1986-87. Med J Aust 153: 376-80.

12. Coggon D (2005) Occupational Medicine at a turning point. Occup Environ Med 62: 281-3.

13. Madan I, Reading I, Palmer KT, Coggon D (2008) Cultural differences in musculoskeletal symptoms and disability. Int J Epid 37: 1181-1189.

14. Ramond A, Bouton C, Richard I, Roquelaire Y, Baufreton G, et al. (2011) Psychosocial risk factors for chronic low back pain in primary care - a systematic review. Fam Prac 28: 12-21.

15. Buchbinder R, Jolley D, Wyatt M (2001) Population based intervention to change back pain beliefs and disability: three part evaluation. Br Med J 322: 1516-1520. in Estonia; Asad Ali Khan for supervision of data collection and checking in Pakistan; Khalil Qureshi for training of field workers and supervision of data collection and checking in Pakistan; Masami Hirai, Tatsuya Isomura, Norimasa Kikuchi, Akiko Ishizuka and Takayuki Sawada for their help with data collection and management in Japan; and Peter Herbison for assistance with data collection in New Zealand.

We are particularly grateful to all of the organisations that allowed us to approach their employees; and all of the workers who kindly participated in the study.

\section{Author Contributions}

Conceived and designed the experiments: DC KTP. Performed the experiments: DC GN KTP KC VEF MHM LMS RH FH RF NH LHB MVM LAQ MR SAF DG EJSV ECH AC SVP CS JMM GD FGB MB MC MMF ACP ES LC PB MK EM KO TS RRH FS AS MMK SSPW RJPJ NS ARW KM NY BN DK MRS HLK VCWH DMU HH SD DM AG. Analyzed the data: GN DG. Wrote the paper: DG. Principal investigator Brazil: VEF. Principal investigator Ecuador: RH. Principal investigator Colombia: LHB. Principal Investigators Costa Rica and Nicaragua: SAF DG. Principal investigator UK: DC. Principal investigator Spain: SV-P. Principal investigator Italy: MB. Principal investigator Greece: ES. Principal investigator Estonia: EM. Principal investigator Lebanon: RRH. Principal investigator Iran: FS. Principal investigator Pakistan: MMK. Principal investigator Sri Lanka: SSPW. Principal investigator Japan: KM. Principal investigator South Africa: BN. Principal investigator Australia: MRS. Principal investigator New Zealand: HH. All authors reviewed the draft manuscript and contributed to its finalization.

16. Ferrari AL, Baptista PCP, Felli VEA, Coggon D (2010)Translation, adaptation and validation of the "Cultural and Psychosocial Influences on Disability (CUPID) Questionnaire" for use in Brazil. Rev Latino-Am Enfermagem 18: 1092-8.

17. Harcombe H, McBride D, Derrett S, Gray A (2009) Prevalence and impact of musculoskeletal disorders in New Zealand nurses, postal workers and office workers. Aust N Z J Public Health 33: 437-41.

18. Harcombe H, McBride D, Derrett S, Gray A (2010) Physical and psychosocial risk factors for musculoskeletal disorders in New Zealand nurses, postal workers and office workers. Injury Prevention 16: 96-100.

19. Hoe VCW, Kelsall HL, Urquhart DM, Sim MR (2011) Risk factors for musculoskeletal symptoms of the neck or shoulder alone or neck and shoulder among hospital nurses. Occup Environ Med 69: 198-204.

20. Matsudaira K, Palmer KT, Reading I, Hirai M, Yoshimura N, et al. (2011) Prevalence and correlates of regional pain and associated disability in Japanese workers. Occup Environ Med. 68: 191-196.

21. Solidaki E, Chatzi L, Bitsios P, Markatzi I, Plana E, et al. (2010) Work related and psychological determinants of multi-site musculoskeletal pain. Scand J Work Environ Health 2010;36: 54-61.

22. Warnakulusariva S, Peiris-John R, Ntani G, Coggon D, Sathiakumar N, et al. (In press) Musculoskeletal pain in four occupational populations in Sri Lanka. Occupational Medicine.

23. Palmer KT, Walsh K, Bendall H, Cooper C, Coggon D (2000) Back pain in Britain: Comparison of two prevalence surveys at an interval of ten years. Br Med J 320;1577-8.

24. Palmer KT, Walker-Bone K, Griffin MJ, Syddall H, Pannett B (2001) The prevalence and occupational associations of neck pain in the British population. Scand J Work Environ Health 27: 49-56.

25. Waddell G, Newton M, Henderson I, Somerville D, Main CJ (1993) A FearAvoidance Beliefs Questionnaire (FABQ) and the role of fear-avoidance beliefs in chronic low back pain and disability. Pain 52: 157-68.

26. Derogatis LR, Melisoratos N (1983) The Brief Symptom Inventory: an introductory report. Psychol Med 13: 595-605.

27. Ware JE, Sherbourne CD (1992) The MOS 36-item short-form health survey (SF-36). Med Care 30: 473-83.

28. Kuorinka I, Jonsson B, Kilbom A, Vinterberg H, Biering-Sørensen F, et al. (1987) Standardised Nordic questionnaires for the analysis of musculoskeletal symptoms. Appl Ergon;18: 233-7. 